\title{
SoM Krisztián \\ Az 1937 M magyar útlevél és nemzetközi összehasonlítása
}

Az útlevelek a hatóságok által gyakran ellenőrzött okmányok közé sorolandók, hiszen határátlépés során a határforgalom-ellenőrző hatóságok, vízumkötelezettség esetén a külképviseletek és tartózkodás meghosszabbításakor az idegenrendészeti hivatalok is minden esetben vizsgálják, ellenőrzik érvényességüket. Ebből eredeztethető, hogy az adott korszakok felfedett vagy vélelmezett közokirat-hamisítás elkövetési módjaihoz igazodva fejlesztenek az okmányokat gyártó állami nyomdák. A növekedő utasforgalom, illetve az úti okmányokkal visszaélő, államhatárt átlépni szándékozók számának növekedésével mindig szükség volt és van olyan nyomdatechnikai, megszemélyesítési és védelmi eljárásokra, amely az ellenőrző hatóságok számára könnyebben felismerhetővé teszik a jogosulatlan beavatkozások jeleit.

A határforgalmat és külföldieket ellenőrző hatósági személyeknek mindig is feladatuk volt az úti okmány érvényességének ellenőrzése, amelyet az eredetiség vizsgálatával kezdtek, azaz ellenőrizték, hogy az okmány eredeti ürlapon, az arra jogosult hatóság által, az elöírásoknak megfelelően került-e kiállításra, illetve nem történt-e benne jogosulatlan módosítás. Mindezek eredményes végrehajtásához az útlevelet ellenőrző személynek az úti okmányok és védelmi jellegzetességeinek, valamint hamisítottsága ismertető jegyeinek ismerete nem (volt) nélkülözhető. Az útlevelek hamisítóit, utánzóit és a hamis / hamisított úti okmányok felhasználóit több évszázada büntetni rendelik, ezt magyarországi törvényben már 1723 -ban rögzítették. ${ }^{1}$

\section{A magyar útlevelek története a XX. század első harmadáig}

A Föld országainak útleveleire a XX. század harmadik évtizedéig még nem alakult ki szabályozott, egységes külalak, bár több ország úti okmánya már a XIX. században a maihoz hasonló elrendezésü volt. A kétféle egységes külalak közül a gyakoribb megjelenése egylapos (kettő vagy négy oldalas, utóbbi esetében az ürlap félbehajtásra került), álló téglalap alakú volt, az első oldal baloldali keskenyebb hasábjában a személyleírás rovatait alakították ki, a címer alatti, jobboldali, szélesebb mezőben a jogosult neve, foglalkozása, úti célja, valamint az okmány érvényességei kerültek kitöltésre, az úti társak a második oldalon voltak felvezetve. Ezt a megjelenést a XIX. század középső harmadában sok ország alkalmazta. ${ }^{2}$ Az első magyar útleveleket az 1848-1849-es forradalom és szabadságharc idején állították ki, a nagy, fektetett lap alakú okmány rendkívül díszes kerettel és arra helyezett, aprólékosan kidolgozott címerrel készült, egyszerü alnyomattal ${ }^{*}$ Az úti okmány okmányszám és az érvényességi idő rovattal rendelkezett. Az 1867-es kiegyezést követő Magyarországon a több részre hajtott egylapos, néhány évente különböző megjelenésủ, de azonos tartalmú útleveleket 1877-ben - a Föld országai közül az elsők között, s néhány évvel megelőzve Ausztriát is - váltotta fel az egységes füzet kialakítású úti okmány. ${ }^{3}$ A XIX. század utolsó három évtizedében a magyar útlevelek - szépen kidolgozott kidomborodó hatású alnyomattal rendelkező ${ }^{4}$ lapjait zsineggel füzték össze; ezen tizenkettő oldalas okmányokban a személyleírás és más adatok öt (1904-től már hat) oldalt töltöttek meg, e kezdeti sorozat hatodik oldalán alakították ki a figyelmeztető szöveget (ezt hamarosan az első belső előzékre helyezték át). Az Osztrák-Magyar Monarchia időszakának magyar útlevelei megjelenésükben, elrendezésükben és terjedelmükben sem voltak azonosak az osztrák úti okmányokkal, csak tartalmukban voltak jelentősebb egyezések. Sok ország a füzet kivitelezést majd csak az I. világháborút követően kezdte alkalmazni. ${ }^{5}$

Az I. világháború előtti évtizedekben a Föld országainak útlevelei esetében általános volt, hogy azok az okmányra jogosultak és úti társaik fényképét nem tartalmazták, mindössze a személyleírásból és - az írástudók esetében — aláírása alapján lehetett végrehajtani a személyazonosítást. Már az első magyar útlevéltörvény 1903 januári országgyülési vitája során javaslat született az arcképek útlevélbe történő rögzítésének elöírására, de az Országgyülés ezt nem szavazta meg és a rákövetkező években sem módosították a jogszabályt; ${ }^{6}$ mindeközben a magyarországi, félárú vasúti jegy váltására jogosító igazolvány már 1898-ban is (!) tartalmazott gyürükapoccsal* (más néven lyukszeg vagy ringli) biztosított és szárazbélyegzö lenyomatával " hitelesített fényképet. Az I. világháború kibontakozásáig a Föld országainak útlevelei csak személyleírást tartalmaztak, képmást azonban nem. A magyar útlevelek esetében a fénykép kötelező csatolását 1915 januárjában írta elő a magyar miniszterelnök, ${ }^{7}$ a legtöbb ország - a kiteljesedö háborúval járó fokozódó gyanakvás és ellenőrzés miatt - szintén azokban a hónapokban tette ezt kötelezővé.

\footnotetext{
* Glosszárium
} 
Mivel a háború alatt bevezetett általános útlevélkényszer állandósult, ezért az újonnan létrejött Népszövetség szervezésében az 1920-as évek során több nemzetközi értekezletet is tartottak útlevelek tárgyában, amelyek egyik célja az úti okmányok tartalmának, elrendezésének egységesítése volt. Az elsőt már 1920. X. 15-e és 21-e között megrendezték, a Népszövetség szervezésével Párizsban „Útlevelek, Vámeljárások és Átutazójegyek Konferenciája” címmel, amelyet 1926. V. 12. és 18. között Genfben újabb szakmai konferencia követett hasonló céllal, ${ }^{8}$ a közép-európai államok részvételével útlevelek és vízumok ügyének egységesítése témakörében, Graz-ban megtartott tanácskozást 1922. I. 27-én megállapodás zárta9 ${ }^{9}$ Az 1929-es genfi értekezlet záró dokumentuma az átutazó kivándorlók úti igazolványát szabályozta. Már az első konferencián meghatározásra került az egységes (úgynevezett „,nemzetközi” vagy „szabványos”) útlevél mintája, amelynek borítója kartonpapír, az első oldala a címen túl a nevek és az állampolgárság jelölésére szolgált, második a személyleírásoknak és gyermekek bejegyzésének volt kialakítva, a harmadik oldal az okmány birtokosának és feleségének fényképét, aláírását tartalmazta, míg a negyedik oldal a területi és időbeni érvényesség felvezetésére volt hivatott; mérete $155 \times 105 \mathrm{~cm}$-ben, terjedelme 32 oldalban lett meghatározva. ${ }^{10}$ A rovatcímeknek és azok kitöltésének kétnyelvünek kellett lennie, amelyek közül az egyik esetében a francia példaként szerepelt a kiállító ország hivatalos nyelve mellett. A betelt útlevelek helyett új kiállítása került meghatározásra, azaz a pótlapok alkalmazását nem támogatták.

A Népszövetség 1920-as szakértekezletén meghatározott egységes útlevélürlapot" a Magyar Királyi Belügyminisztérium 1922 őszén - Magyarországnak a Népszövetséghez történő csatlakozásához is időzítve - vezette be, ${ }^{11}$. Az új magyar útlevél - a borító puhább kivitelét és az 5-5 milliméterrel megnövelt nagyságát nem számítva - maradéktalanul megfelelt az előírásoknak. ${ }^{12}$ Azonban az egységes külalakot több ország, mintegy évtizednyi késéssel kezdte alkalmazni: utolsók között a Népszövetség alapító tagja, Franciaország amely csak 1928-ban kezdte meg a füzet formátumú útlevelek kiállítását, azonban ez még eltért a genfi konferencián ajánlott szerkezettől ${ }^{13}$. A korábbi összehajtott lap formátum helyett az 1931-töl kibocsátott sorozatoknál alkalmazták először a füzet formátumú útlevelet.

Az 1922-ben bevezetett magyar útlevélürlap 1936-ig számos módosításon esett át. Ezek egy része a bélyegilleték címlete vagy képe miatt történt, de néhány esetben az okmánybiztonság fokozása indokolta a változtatást, és ezen okok eredményeztek lényegi eltéréseket. A korábbi vízjelet" 1927-ben módosították: a hullámvonalak által elválasztott sorokban már az állam megnevezése volt olvasható. ${ }^{14} \mathrm{~A}$ lapoldalak sorszámozása lyukasztással 1927-ben kezdődött meg (az okmány gyári számának betűjel nélküli számsorával), ${ }^{15}$ kezdetben nagyobb, majd hamarosan kisebb méretü kialakítással. A lapok füzését 1929-től módosították, az addigi zsinegfüzés helyett fémkapcsozást alkalmaztak, mégpedig a középső esetében középről kifelé tüzve, oly módon, hogy majdan a borító rejtse a kapocs záródását. Az alsó és felső kapocs a boritót is rögzítette, annak külső része felöl középen záródott; ugyanakkor a borító keményebb kartonból készült, amelyet ragasztva vászonnal borítottak be. Az 1922 M magyar útlevél és későbbi módosított változatai kezdetben a kor jó minőségü útlevelei közé tartozotak, számos ország még két évtizeddel később sem vezetett be korszerübbet.

Magyarországon, az 1920-as és 1930-as évek során magyar állampolgár részére kétféle útlevelet állítottak ki az általános távolsági utazáshoz: útlevelet és diplomata útlevelet. Az útlevél kiváltásának alap illetéke helyett, ha a kérelmező ,,a szokásos napszámot meg nem haladó keresetből él, ${ }^{16}$ vagy ha közszolgálatban lévő alkalmazott vagy nyugdíjas, és ezek ellátást élvező hozzátartozója" ${ }^{17}$ akkor a díjak egészének jelentősen mérsékelt összegét kellett csak megfizetnie (amely 1934-től 20 helyett 4 pengő, majd 1937-től 15 helyett 3,50 pengő volt). ${ }^{18}$ Az állami szolgálati feladattal külföldre utazók 1940 végéig (magán)útlevelet kaptak, az utazási cél rovatban azonban jelölésre kerül(hetet)t, hogy az: „hivatalos officiel". A magyar tengerészek szolgálati könyveit sok ország elfogadta (útlevélpótló) úti okmányként. A diplomata útlevelet a Császári és Királyi Külügyminisztérium, majd a Magyar Királyi Külügyminisztérium állította $\mathrm{ki}^{19}{ }^{19}$ a tényleges diplomáciai feladatokat ellátó személyek és közvetlen családtagjaik részére. Jogosult volt még ezen úti okmányra a kormányzó felesége az államfö útlevél nélkül, diplomáciai bejelentés alapján lépte át az államhatárokat - és a HABSBURG-LOTHARINGIAI-ház magyar állampolgárságú tagja is. ${ }^{20} \mathrm{~A}$ kormány tagjai csak hivatalos útjaikon használhatták a diplomata útlevelet, Országgyülés más tagjai ezen okmányra nem voltak jogosultak, sőt a (magán)útlevél csökkentett illetékének igénybevételére is csak az általános feltételek fennállása esetén voltak jogosultak. ${ }^{21}$ A távolsági utazásban részt vevők meghatározott köre útlevél nélkül első alkalommal 1925-ben, csoportos úti okmánnyal utazhattak ki Magyarországról, majd ezt tágabb körnek 1936 nyarától engedélyezték ${ }^{22}$. A 15

\footnotetext{
* Glosszárium
} 
éven aluliak 1930 végétől Ausztriába és Németországba úgynevezett igazoló jeggyel is utazhattak. ${ }^{23}$ A tengeri hajón szolgálatot teljesítők 1932-től tengerész szolgálati könyvvel ${ }^{24}$ is átléphették a magyar államhatárt.

\section{Útlevél-hamisítási módok az 1920-as, 1930-as években}

A hamis közokirat készítőjét vagy valódinak tartalmát meghamisító személy cselekményét az -1930as években is hatályos - 1878. évi büntető törvénykönyv „büntettként” minősítette és öt évig terjedő börtönnel sújtották. ${ }^{25}$ Azonban eredeti útlevélnek meghamisítását, illetve ennek felhasználását a szabálysértések közé sorolták, s egy hónapig terjedhető elzárással és 200 koronáig terjedhető pénzbüntetéssel sújtották. ${ }^{26}$ Változást majd csak az 1903. évi útlevélügyről szóló törvény 1940-es módosítása hozott, amikortól már vétségnek minősült és egy évig terjedhető fogházzal büntették a hamisított útiokmányok felhasználóit. ${ }^{27}$

Az útiokmányok hamisításának módozatai folyamatosan bővültek - ahogy újabb és újabb biztonsági elemmel nehezítették meg a tartalom jogellenes változtatását -, miközben a közelmúlt okmányait továbbra is hamisítják évszázados módszerekkel is. Ennek oka az azonos célokban és sokszor a változatlan lehetőségekben rejlik. Az első - a meghamisítás felismerése érdekében alkalmazott - jelentősebb elörelépés volt a kitöltendő rovatok felületén alkalmazott alnyomat, majd annak az egész oldalakra kiterjedő kivitelezése, ezt követően a vízjeles ürlapok bevezetése is jelentős lépésnek számított. Korszakot indító változtatás a fénykép kötelező elhelyezése jelentette az 1910-es évek közepétől, majd az 1920-as évektől fokozatosan, az egyes országok által alkalmazott félig vagy ritkábban egészében rejtett varrás volt jelentős újítás. Természetesen az okmánytervezés és -gyártás folyamatosan vezet(ett) be újítást, de a hamisítások egy része az egy évszázaddal ezelőtt is létező beavatkozás módszerével készült és azok jeleivel rendelkezik.

Az adatok hozzá- és / vagy átírása, törlése az útlevelek legrégebbi hamisítási módjai. A hozzáírás igen gyakori elkövetési mód volt elsősorban az úti társak bejegyzését lehetővé tevő okmányokban, az engedély nélküli utólagos beírással új személlyel egészítették ki az utazásra ,jogosultak” körét, akinek határátlépését így kívánták megvalósítani például nőcsempészés estében. Átírással elsősorban érvényességi időt, életkort (születési dátumot) módosíthattak, adat törlését gyakorta átírással együtt alkalmazták.

A lapcsere az 1870-es évektől - az akkor még csak néhány ország által alkalmazott - füzet kivitelezésü útlevelekkel jelent meg, még a XX. század első két évtizedében is a lapok madzaggal kerültek összefüzésre (ezt rögzítették és hitelesítették címkével és bélyegzőlenyomattal), vagy fémkapcsokkal tüzték össze azokat. Mindkét megoldás lehetővé tette az okmány szerkezetének megbontását és lapok cseréjét újakkal, oly módon, hogy az nehezen lett felismerhető. A lapcsere elsősorban a beutazási engedélyek (vízumok), vagy korábbi úti okmányból úti társak bejegyzésének áthelyezését szolgálta.

A fényképcsere - a különböző államok által az arcmások csatolásának 1914 és 1915 közötti bevezetését követően - gyakori elkövetési móddá vált az útiokmányokban, a fényképet az első évtizedekben még gyakorta csak egy gyürükapoccsal biztosították. A fényképcsere oka elsősorban az volt, hogy az elkövetők általában előnyben részesítették, ha saját képmásuk szerepelt az okmányban, ezzel nagyobb magabiztosságra tehettek szert. A fénykép cseréjét ekkor úgy valósították meg, hogy azt vagy a lyukszeggel együtt eltávolították és az új képpel újat helyeztek el, vagy a gyürükapcsot körbevágták és az új fényképen lyukat alakítottak ki, amelyet ráigazgattak a lyukszeg peremére / pereme alá.

$\mathrm{Az}$ okmányok egészének vagy egyes lapjának utánzása ezen évtizedekben jelentős nyomdatechnikai gyakorlati tudást és sok ráfordítást igényelt, az eszközök / berendezések értéke és méretei miatt nyomdai hátteret követelt; ezért ezt a megoldást csak nagyobb mennyiség előállítása során alkalmazhatták. A bankjegyek esetében tapasztalható volt, hogy az alnyomat-rendszereket már az 1910-es évek legelején is igen jó minőségben utánozták, ${ }^{28}$ a hamisítás során alkalmazott módszerek még az 1920-as évek második felében is kihívást támasztottak az állami megrendelőknek és nyomdáknak. ${ }^{29}$ Ebből adódik, hogy az útlevél lapjainak utánzása a XX. század elején síknyomtatással is megoldható volt, de a hamisítóknak csak nagy mennyiségben lehetett kifizetődő.

A láttamozások, bélyegzőlenyomatok esetében a törlés, törlés-átírás, átírás, hozzáírás, és az utánzás is egyaránt előfordult, amely célja általában belépési vagy tartózkodási jogosultság megszerzése volt (érvényességi vagy tartózkodási időnek, beutazások számának, jogosultak neveinek módosításával).

\section{Az 1937 M magyar útlevél bevezetésének történelmi előzményei, okai}

I. Sándor jugoszláv király 1934. X. 9-én hadihajó fedélzetén kéthetes hivatalos látogatásra érkezett Franciaországba. Marseille-ben, a délutáni partraszállást követően, Louis BARTHOU francia külügyminiszterrel gépkocsiba ülve megkezdték hivatalos programjukat. Azonban a francia kikötőváros 
fellobogózott utcáin, népes tömeg sorfalai között haladva, egy férfi lépett a jármúvükhöz és maroklőfegyverét elsütve halálosan megsebezte az államfőt és a francia külügyminisztert, és a tömeg irányába is leadott lövéseket; a gyilkos a merényletet követően szerzett sebeibe halt meg. A királygyilkosság kapcsán azonnal több nyomozás is indult Európa számos országában, így Német- és Olaszországban, s Csehszlovákiában is, mivel az egyik elkövető csehszlovák útlevelet használt, mint kiderült hamisítottat. A francia hatóságok hamar megállapították, hogy a merénylő maga bulgáriai macedón származású, szélsőséges forradalmár volt, s büntársak segítették cselekményét.

A királygyilkosság kapcsán Európa több országnak sajtója számos alkalommal is magyarországi szálakat tárt a nyilvánosság elé - a merényletben részt vevőket Jankapusztán képezték ki -, amelyhez hasonló következtetéseket vontak le a nyomozásban érintett egyes államok kormányhivatalai is. ${ }^{30} \mathrm{Az}$ elkövetők részben nem-magyar állampolgárnak, de budapesti lakosnak vallották magukat, illetve két, — az ügy kapcsán vádolt - személy vallomásában azt közölte, hogy magyar útlevelet használtak fel. A magyar rendőrségi nyomozás eredménye ezeket hivatalosan cáfolta és feltételezte, hogy ha magyar útlevél birtokában is voltak, akkor az hamis / hamisított lehetett. A magyar kormány nem tagadta, hogy Magyarországon élő délszláv emigránsok közül lehettek páran, akik részt vettek a merényletben, azonban erről tudomásuk nem volt, s magyar hatóság vagy magyar állampolgár nem érintett e büncselekményben. ${ }^{31}$

A magyar útlevél minősége és hamisíthatósága nemzetközi előtérbe került - bár az akkoriban kiállításra kerülő 1922/1929 M magyar úti okmány minőségét tekintve sok országétól nem volt elmaradva -, ezért a magyar kormány annak felülvizsgálatát és fejlesztését kezdte meg, annak ellenére, hogy Európa több állama sem vezetett be előnyösebb kivitelủ okmányt.

Az útlevél igénylésének és kiadásának folyamatát - szintén nemzetközi észrevétel miatt szigorította a belügyminiszter 1935 legelején kiadott rendelete. ${ }^{32}$ Az útlevéligénylő lap kiállításakor a kérelmezőnek személyesen kellett megjelenni - ami alól csak „komoly oknál fogva” adhattak felmentést -, és személyesen kellett a csatolt két fényképet aláírni; igazolnia kellett továbbá a hatóság illetékességi területén fél évnél hosszabb idejű tartózkodását és okmányokkal kellett bizonyítani állampolgárságát ${ }^{33}$ és személyi adatainak valódiságát is. A miniszter továbbá megtiltotta, hogy útlevelet egy évnél hosszabb időre kiállítsák vagy meghosszabbítsák, mivel „lehetőleg rövid időn belül a jelenleg forgalomban levő útlevélnyomtatványok helyett, melyek a szerzett tapasztalatok szerint könnyen hamisíthatók, új mintájú, a hamisítást a lehetőségig kizáró útlevélnyomtatványok bevezetését" szándékozott elrendelni. ${ }^{34} \mathrm{Az}$ új magyar útlevél bevezetését később kihirdető rendelet indoklásában is az „,egyre gyakrabban előforduló útlevél-hamisítások” kerültek megemlítésre. ${ }^{35}$

A Magyar Királyi Belügyminisztérium felügyelete alatt már 1934 utolsó heteiben megkezdődött a leendő új magyar útlevélürlap tervezése, amely során vizsgálhatták a korszak úti okmányait és ezek alapján számos egyedi, újszerü vagy új megoldás alkalmazása mellett döntöttek. Ezek közül is kiemelkedhetett a csak a román hatóságok által, akkor már közel két év óta kiállított útleveleken alkalmazott, első belső előzékre négy, félig rejtett gyürükapoccsal rögzített fénykép, amely alapul szolgálhatott egy továbbfejlesztett, előnyösebb magyarországi változathoz. A tervezés és kísérletezés elhúzódott, így az 1922/1929 M magyar útlevélből 1935-ben, és még 1936-ban is kellett ürlapkészletet utángyártani. ${ }^{36}$ Eközben, 1936 augusztusában a Magyar Királyi Belügyminisztérium „bizalmas értesülés" útján tudomást szerzett arról, hogy a prágai állami nyomda a magyar útlevelek utánzására (hamisítására) tett előkészületeket; ezekkel a csehszlovák hírszerző ügynököket kívánták ellátni. Ezért a miniszter valamennyi határforgalom-ellenőrző rendőrhatóságot utasított az útlevelek fokozottabb vizsgálatára, s a „nem egyéni érdekből elkövetet egyéni hamisítás” felfedése esetén a Magyar Királyi Belügyminisztérium illetékes osztályát azonnal értesíteni kellett. ${ }^{37}$

\section{Az 1937 M magyar útlevél múszaki leírása és összehasonlítása}

Az 1937 M magyar útlevél, majd a szolgálati útlevél ürlapjait - a belügyminiszter aláírásával meghatározott leírás alapján a pénzügyminiszter megrendelésére ${ }^{\mathbf{3 8}}$ - a Magyar Királyi Állami Nyomda gyártotta, Budapesten, a budavári Kapisztrán tér 1. szám alatt álló klasszicista épületében. A nyomda elsősorban kormányzati nyomtatványokat, különféle hivatalos ürlapokat (többek között anyakönyvi kivonatokat) állított elö, ezeken felül postai és illetékbélyegeket, levelezőlapokat, valamint biztonsági okmányokat készített (a magyar útleveleket ekkor már évtizedek óta; bankjegyet csak 1920-ban), mindezek mellett számos könyvet is nyomtatott. ${ }^{39} \mathrm{~A}$ széles, több részbe hajtott ívböl álló magyar diplomata útleveleket ellenben - a különleges hordozóanyaga miatt is - a papírgyártással is foglalkozó vitéz SZÉNÁSY Béla budapesti nyomdája készítette. ${ }^{40}$ 
Az 1937 M magyar útlevél ürlapokat több változatban gyártották, ennek bemutatásához fontos megismerni ezen okmány gyártásának folyamatát is. ${ }^{41} \mathrm{Az}$ okmánypapírt ívekben nyomtatták alnyomattal és előre nyomtatott szövegekkel, majd a hajtogatott ívet füzték, ezt követően méretre vágták, végül perforálták. Az így létrejött füzet első és utolsó lapjának külső részét hozzáragasztották a külön legyártott, vászonnal bevont borítóhoz, azaz kötötték. A kész útlevélürlapokat a kiállító hatóságoknak az Állami Nyomdától kellett megrendelniük. Az 1937 M magyar útlevelek részletenkénti nemzetközi összehasonlítása során az azonos időszakban (1936 és 1939 között), az akkori 73 független állam közül hat kontinens 27 országának honi útlevélhatóságai által kiállított útleveleit vettem figyelembe. ${ }^{42}$

Az 1937 M magyar útlevélürlapból 1936-ban gyártottak elöször, majd az azt követő három évben újabb készleteket állítottak elő. Az első sorozatból készítettek mintaokmányokat is - a magyar útlevélkiállító hatóságok, $\mathrm{s}$ estelegesen a magyar társszervek és a külföldi hatóságok tájékoztatása céljára -, amelyek a „000000” gyári sorszámot viselték és az oldalakat ferdén, nagy méretü betűkkel kialakított „MINTA” szóval felülbélyegezték. ${ }^{43}$ Az útlevélürlapokból az Állami Nyomda 1936 és 1938 vége között összesen kb. 365.000 darabot gyártott le. Több szempontból kiemelkednek az 1939-es nyomdai jelzettel legyártásra került okmányok, amelyből igen jelentős mennyiség (kb. 200.000 darab) készült, s ezen jelzettel előfordult visszaszámozott - azaz forgalomba nem került korábbi okmányszámokkal újragyártott - útlevél is. Azonban a negyedmilliós példányszámnak a nyomtatás évében csak kisebb részét kötötték be borítóval, a fennmaradó összefüzött, sorszámozott ürlapfüzet-készletet ezt követően raktározták, és a korábban készre gyártott ürlapok kifogyása elött kötöttek be újabb, jelentősebb mennyiséget, amelyek részben az eltérő borítónyomatok alapján ismerhetőek fel. (A füzetek II. világháború alatti tárolása elsősorban a lecsökkent ürlap-igény miatt történt. A borítót azért nem ragaszthatták a füzethez, mert a szegecs készítéséhez szükséges fém rudacskák nem tették lehetővé a kész útlevélürlapok teljes összecsukását, így nagyobb mennyiség hosszú távú tárolását sem.).

A lapok alapanyaga törtfehér árnyalatú ,a szokásosnál kisebb mértékben enyvezett, vegyszerekkel preparált" okmánypapír volt. ${ }^{44}$ A papír gyártása során ismétlődő, vonalas kivitelezésű, negatív vízjelet alakítottak ki, amely egyszeres hullámvonalak által elválasztott sorokban, soronként eltolva olvasható $34 \times 310 \mathrm{~mm}$ méretü „MAGYAR KIRÁLYSÁG” feliratot keretes betűkkel ábrázolt, e típust 1927 óta alkalmazták az útlevélgyártás során; a vízjel a kivágott lapokon véletlenszerüen helyezkedett el. Az okmánypapír - dr. PUSZTASZERI Ferenc írás- és papírszakértő által megalkotott egyedi vegyi összetétele lehetővé tette, ${ }^{45}$ hogy a vegyi törlések hatására a papír esetenként elszíneződjön, ${ }^{46}$ továbbá a kitöltéshez rendszeresített vegytintától eltérőek alkalmazása során, több fajta esetében ez láthatóvá váljék (kissé szétfolyjon, „vérezzen”, vagy a lapon átüssön) ${ }^{47}$.

A vízjel gyakori védelmi elem volt a vizsgált államok úti okmányai esetében, azonban ritkának számitott annak gazdag képi megjelenése vagy kéttónusú kivitelezése, de nem volt példa nélküli a vízjel nélküli papír felhasználása sem. A vizjelek szempontjából a lengyel útlevelek okmánypapirja emelkedik ki, amely szöveget és árnyalatos kivitelezéssel az állami címert tartalmazta, s mindezt a lapoldalon pozícionáltan (meghatározott elhelyezkedéssel) helyezték el; az olasz úti okmányok vízjele abban volt egyedi, hogy a lapok oldalszámai a megfelelö oldalról nézve olvasható volt a - szépen kidolgozott vonalas, szöveget, keretvonalakat és az állami címert ábrázoló - pozicionált vízjel részeként.

Az oldalak nyomtatásaihoz - mind az alnyomathoz, mind az előre nyomtatott szöveghez és a bélyegképhez is - magasnyomtatás " eljárást alkalmaztak. A színek alapján kétrétegü nyomtatással készültek a magyar útlevelek, az alnyomat zöld mintázatára fekete színü elöre nyomtatott szöveget vagy sötétzöld illetve kék színü bélyegképet vittek fel.

A kifutó (azaz a vágandó éleken túl is kialakított) alnyomatot oldalpár-képet hordozó felületek ismétlődő nyomtatásával alakították ki. ${ }^{48}$ A lapok alnyomata - amelynek színe a különböző nyomdai jelzetúek csoportján belül is kissé eltér: halványzöld, zöldessárga, zöld vagy olajzöld - pozícionáltan (illesztetten) került kialakításra; középen 24 ágú, vonalkák alkotta csillagra helyezett 24 sugarú napkorongmintával övezve - amely külső és belső körvonala csak 3/4-ed körív hosszú - a csertölgy és olajágak övezte magyar kiscímer volt látható. Az oldal többi részét kitöltő alnyomat - egymás mellett és fél mintával eltolva egymás alatt - ismétlődő magyaros díszítményben elhelyezett, kissé díszes, dőlt betüs „MAGYARORSZÁG” felirat volt; ezen látszólag azonos minták soronként megegyezően kerültek kialakításra és minden sor az következő utáni sor mintájával mutat teljes azonosságot, az egymást követő sorok mintái között kisebb, de nyilvánvaló eltérések találhatóak (elsősorban díszítmény-részletek méretbeli eltérései, összefüggések alapján). ${ }^{49}$ Az alnyomat díszítménye stílusjegyeiben azonos volt a LÉGRÁDY Sándor által tervezett, 1934-ben bevezetett pengős illetékbélyegek mintázat-

\footnotetext{
* Glosszárium
} 
részletével. ${ }^{50}$ A zöld színű festék egyedi összetételủ alapanyag volt, amely a különböző vegyi alapanyagok jelenléte esetén elszíneződést mutathatott (ún. reagens festék). ${ }^{51}$

Az 1937 M magyar útlevél tartalmának felépítését módosították az 1920-as párizsi konferencián rögzítettekhez képest. Terjedelme 44 oldal lett, a 3. oldal egész tartalmát - fénykép és aláírás - az első belső előzékre helyezték át. A 4. oldal rovatait - területi és időbeni érvényességek - a 3. oldalon alakították ki. Az első belső előzéken helyezték el az útlevélre jogosult(ak) arcképé(i)t és aláírásá(i)t, valamint a kiállító hatóság képviselőjének aláírását és nedves-bélyegzőlenyomatát. Az első oldalon az állami címer mellett az okmány terjedelmét, illetékkategóriáját és az illetékbélyeg képét tüntették fel, mindezek alatt az okmány és az állam megnevezése olvasható, amelyet egymás alatt az útlevél (iktató)számának, a tulajdonos és a vele utazó feleség nevének, valamint gyermekei számának rovatai követnek, amelyet az állampolgárság feltủntetése zár. A második oldalon a személyleírás alábbi rovatait alakították ki függőlegesen osztottan a tulajdonos és feleség részére is kitölthető módon - foglalkozás, születési hely és idő, lakhely, családi állapot, vallás, termet, arc (alakja), szem (színe), haj (színe), különös ismertető jel, mindezeket a három gyermek bejegyzésére szolgáló rész zárta, ahol kitöltendő volt a kiskorúak neve, kora és neme. A negyedik oldalon került kitöltésre a területi érvényesség, az utazás célja, az útlevél lejárta, a kiállító hatóság megnevezése és a kiállítás kelte. A negyedik oldal a magyar hatóságok útlevél kiállításhoz, -érvényességhez kapcsolódó hivatalos bejegyzései vagy az azokra hivatkozások részére volt fenntartva. Az ötödik, hatodik és hetedik oldalon 2-2 meghosszabbítás-rovat volt kialakítva, külön felülettel a beragasztandó illetékbélyegeknek. Az elöre nyomtatott szövegek eddig az oldalig magyar és francia kétnyelvüek voltak. A nyolcadik oldaltól a negyvenharmadikig a hatósági bejegyzések, a vízumok és az átléptető-bélyegzők elhelyezésére szolgált, ezen oldalak előre nyomtatva csak a gondolatjelek közé zárt oldalszámot tartalmazták a felső negyedben, középre igazítva. A negyvennegyedik oldal a külföldre utazók részére figyelmeztetést, a nyomdai jelzetet és az okmány gyári sorszámát tartalmazta. A hátsó belső előzéket előre nyomtatott szöveg nélkül alakították ki.

A sötétszürke, vagy fekete színü előre nyomtatott szöveget azonos betütípussal hozták létre, amely alól kizárólag az állampolgárságot jelölő: „magyar” illetve „hongroise” szavak és a meghoszszabbítás rovatok „P. H.” rövidítéseinek eltérő karakterei képeztek kivételt. Az elöre nyomtatott szövegek szedései némileg eltértek (például a kettőspont írásjelek egyes jelzetek esetében szóközzel, mások esetében szóköz nélkül kerültek kialakításra, a 2. oldal gyermekrovatának „Âge:” ékezetének mérete és elhelyezése, vagy a kapcsos zárójelek eltérő kialakítású változatai ${ }^{52}$ ). A szövegnyomatok védelmi jellegzetessége a kapcsos zárójelek (összefoglaló jelek), amelyek közül az 1. oldal második, középső és a 2. oldal első jele - a többivel ellentétben - bal oldalra mutatnak. Az első oldal felső negyedében illetékkategóriát jelölő római szám is feltüntetésre került az előre nyomtatott fekete szöveg részeként, azonban ismert több példány is, ahol az „I.” számjegy elé utólag egy „I” számot nyomtattak, hogy az megfeleljen a nyomtatandó 5 pengős bélyegképnek. Szintén az első oldal esetében, a 965/1937. nyomdai jelzetü ürlapoknál ismert, ahol a szabványnak megfelelően írásjel (pont) az állammegnevezés francia nyelvü változatát követi illetve valamivel gyakoribb e változatnál, hogy az említett szót nem zárja írásjel. A 44. oldal alján elhelyezett nyomdai jelzet számjegyeinek esetében kétfajta betütípus alkalmaztak, a 4039/1936. teljes illetve a 965/1937. jelzetek alsóbb gyári számú ürlapjainak számjegyei eltértek a 965/1937. jelzetek felsőbb sorszámúitól és a későbbi nyomdai jelzetekétől. Szintén a 44. oldalon, az előre nyomtatott figyelmeztetés szövege kissé eltérö szótávokkal, de azonos sorszélességgel került kialakításra. A kezdeti változat módosulatai, a különböző sorozatok tévnyomatai, nyomathiányai kissé alább kerültek ismertetésre.

Az útlevélürlapok 50 fillér és 5 pengő címletü elöre nyomtatott illetékbélyeg-képet tartalmaztak a 4792/1938. jelzetet kivéve, amely csak 5 pengős változatban készült. A nyomtatás utolsó szakaszában kialakított, sötétzöld 50 filléres és kék 5 pengős bélyegkép igen jól kidolgozott és részletgazdag, megegyezik az azonos címletü, 1934. november 1-én bevezetett általános illetékbélyegekével; a filléres címletet EGRY Zoltán, a pengőst LÉGRÁDY Sándor tervezte. ${ }^{53} \mathrm{Az}$ útlevél igénylésének, ügyintézésének illetéktétele, és így a bélyegilleték is 1943. július 1-töl megváltozott (50 fillérről 1 pengőre, illetve 5 pengőről 10 pengőre) ${ }^{54}$ azonban új okmányokat új címletủ bélyegképpel - a meglévő nagy mennyiségü, félkész készlet miatt - nem gyártottak le; a kiállító hatóságok továbbra is a meglévő ürlapokat használták fel ezt követően is, de azokat kiegészítették 50 fillér illetve 5 pengő névértékü illetékbélyeg beragasztásával és felülbélyegzésével.

Az alnyomat általános védelmi elem volt a vizsgált államok okmányai esetében, azonban ritkának számitott a gazdag képi megjelenés. E szempontot vizsgálva a danzigi, a holland, a litván, a német 
(1937-ig, majd 1942-töl) és a svájci útlevelek emelkednek ki gazdag részletekkel, a legkevésbé elönyös alnyomatot az argentin, a francia, a kínai és a svéd okmányok tartalmazták, míg a dán és a lengyel úti okmány alnyomat nélkül készültek. Az alnyomat és az elöre nyomtatott szöveg általánosan két különbözö szín nyomtatásával készült, ez alól az iráni útlevél kivétel, ahol három szint alkalmaztak egymásra rétegezve (az alnyomat két szinrétegböl állt, amelyre az elöre nyomtatott szöveget vitték fel harmadik szinnel, ${ }^{55}$ ez a német útleveleknél majd 1942-ben jelenik meg). A szivárvány (színátmenetes) nyomtatást a vizsgált idöszakban kizárólag a brit útlevelek elsö belsö elözékének díszitményéhez alkalmazták (ezt is csak az 1939-ben bevezetett sorozatnál).

Az útlevelek adatot hordozó oldalainak elhelyezkedését és elrendezését figyelembe véve az országok többségének az okmányai - a vizsgált idöszakban - az 1920-as útlevélszabvánnyal azonosak voltak; azonban számos ország részben vagy egészében eltért ettöl, ${ }^{56}$ néhány állam az úti okmányait csak a saját nyelvén alakitotta és töltötte ki. ${ }^{57}$

Az alaptípustól - 4039/1936. nyomdai jelzetủ útlevelektöl (1937/1936 M magyar útlevélürlap) eltérően, a 4504/1938. jelzetü okmányok magasabb gyári számú példányaitól kezdődően ${ }^{58}$ az elöre nyomtatott szövegezésén részben módosítottak, amelyet tovább alkalmaztak az 1683/1939. jelzetúeknél is (1937/1938 M); legkorábbi ismert megszemélyesítése 1939 májusa. Az 1. oldalon az „útlevél” szavak nagyobb betűtávval lettek szedve, így az alatta lévő állammegnevezésekkel ún. sorkizárt - azonos sorszélességü - lett; alább, az útlevélszám rovat francia szövegének " $\mathrm{N}^{\mathrm{o}}$ " rövidítésének „o" betüje lejjebb, a vízszintes középtengelyére került. A 2. oldalon korábban elhelyezett hatodik - a vallás feltüntetésére szolgáló - rovatot eltávolították, bár a korábbi sorozatok későbbi megszemélyesítése során továbbra is kötelező volt azok kitöltése; ugyanezen oldalon a lakhely rovatcím az ürlapcsoport jelentős hányadánál egy betűvel hosszabb, „Lakhelye” lett (ez már nem sajátja az 1939-es jelzetü okmányoknak). A 3. oldalon az utazás céljának rovatát már nem alakították ki, helyébe a területi érvényesség rovatát három sorral, kilenc sorra bővítették ki. A 44. oldalon kialakított figyelmeztetés a korábbi jelzetủeknél 10 bekezdés összesen 36 sorában került megszövegezésre, a módosítás alapján ez 9 bekezdésben 33 sorra csökkent (a korábbi háromsoros 8 . bekezdés teljes tartalmában elhagyásra került), valamint itt az oldalszám alatt kevesebb sortáv lett hagyva. A csökkentett tartalmú, 4504/1938. nyomdai jelzetủ (1937/1938 M) útlevélürlapból készült perforált „,000000” (de magasnyomású nélküli) gyári számú mintapéldány, amely a m. kir. Belügyminisztérium részére felterjesztésre került, hogy az 1939-ben gyártandó útlevélürlapokat e szerint véleményezze, módosítsa az arra illetékes személy. ${ }^{59}$ A meghatározott módosításokkal jóváhagyott útlevél 1939. IV. 21-ei keltezésű, ezen az első belső előzéken az addig sorkizártan tördelt „délivré le passe- port” szövegrészletet elválasztás nélkül rendeli (így az 1939-es nyomdai jelzetü útleveleken a „le passeport” szavak teljes egészében az utolsó sorba kerültek), illetve a második oldal „Lakhelye” rovatcím utolsó betüjének törlését írta elő (lsd. nyomdahibák alább). ${ }^{60} \mathrm{Az}$ 1939-es nyomdai jelzetủ útlevél csekély mértékủ módosítása tartalmi változást nem jelent ezért önálló altípust nem képvisel, mindössze tördelési alcsoportot, így jelölése: 1937/1938 M (1939).

Az 1937 M magyar útlevél ürlapok nyomtatási eljárásából ismertek téves változatok is: az első csoportot a szedési hibával, míg a másodikat nyomtatási szakasz hiányával forgalomba kerültek alkotják.

A fekete, elöre nyomtatott szövegnek ismert négy hibás szedésủ változata, azaz tévnyomata:

a) A 4504/1938. nyomdai jelzetủ esetében, ritka előfordulással ismert, hogy a 7 . oldalon található 5 . meghosszabbítási rovat lejárati dátumát jelölő sor és a keltezés között háromsornyi többlettávolsággal lett kialakítva. (III. sz. melléklet)

b) Szintén a 4504/1938. nyomdai jelzetü, 1938-as rövidített szövegtartalmú esetében, ritka előfordulással ismert, hogy a 2. oldalon található „Lakhely” rovat magyar címe birtokos jelzővel olvasható, azaz „Lakhelye”. E tévnyomat előfordulása ritka, de e változatból mintaokmány is készült. ${ }^{61}$

c) A 4792/1938. nyomdai jelzetü esetében, igen ritka előfordulással ismert, hogy a 44. oldalon elhelyezett figyelmeztetés nyolcadik bekezdés kezdő sorában a negyedik szó „még” helyett „m g” módon, azaz „é” betủ hiányával, az azt helyettesítő távközzel lett szedve. ${ }^{62}$ (IV. sz. melléklet)

d) Szintén a 1683/1939. nyomdai jelzetü esetében, ritkább előfordulással ismert, hogy az első belső elózéken - az akkor már szabvány szerint - elválasztás nélküli francia „passeport” szó helyett a korábbiakkal azonos változatban: „passe- port” módon olvasható.

A bélyegképhez kapcsolódóan - amelyet a nyomtatás utolsó szakaszában helyeztek el - ismertek nyomathiányos változatok: igen ritka előfordulással - nyomdai jelzettől függetlenül - ismert, hogy a bélyegilleték képe nem került nyomtatásra az első oldal felső, jobboldali sarkába; egy esetben egyúttal az illetékkategóriát jelölő római szám is hiányzik, amely azonban eredetileg az előrenyomtatott fekete szövegrész része, így ez kettős hiány. ${ }^{63}$ 
A kötészeti eljárások során a lapok füzését az előzékeknek borító felöli felületén vászonnal megerősített közepénél - a 22-23. oldal felezésére nyomtatott két korong közé kialakított folytonos vonal segítségével - gerincvarrással alakították ki, esetenként eltérő öltéstávolsággal vékony, egyszeres fehér füzőszállal (ezen füzési mód ezzel az útlevéllel jelenik meg Magyarországon). Az összefüzött lapoldalakat derékszögű sarkokkal 154-155×91 mm méretüre vágták, majd az előzéklap kivételével, az oldalszámozott lapoldalakat az okmány egyedi gyártási számával lyukperforálás* módszerével sorszámozták, az 1-22. és 23-44. oldalig két részletben. E hatjegyü számsor magassága $10 \mathrm{~mm}$, a lyukak átmérője $0,9 \mathrm{~mm}$ volt, a lyukasztás minősége igen jó volt, kis kiemelkedő peremmel; az egyes számjegyek $6 \times 4$ lyukasztó tü által felosztott felületen lettek kialakítva. E sorszám a 44 . oldalon kialakított figyelmeztetés szövege alatt, a nyomdai jelzett mellett magasnyomású sorszámbélyegzővel, fekete színnel is feltüntetésre került.

Az okmány 159-160×94-95 mm-es borítóját kemény rétegezett-ragasztott karton lapok alkották, amelyek középső rétegének közepén széles lyukat alakítottak ki, ide helyezték a fénykép rögzítésének alapját képező egyszerü eszközt: téglalap alakú fém lapkára forrasztott kettő, $1 \mathrm{~mm}$ átméröjü és $3 \mathrm{~mm}$ hosszú rudacskát, amelyek külső vége kúp alakúra volt eldolgozva (ezek alkották a fényképrögzítő szegecsek magját). Az olajzöld vászonnal borított fedőlap előoldalán aranyszínủ fólianyomtatással lett kialakítva az állami címer és a szövegezés, amely az államra és az okmányra utal. Az előzék lap hátsó felületének ragasztóval történt felületkezelését követően rögzítették a füzetet a borítóhoz, így a füzés félig rejtett lett; az első belső előzék lapját átszúrták a fedőlapba rejtett talapzatú, 2,5 mm-re kiemelkedő kúpos fejü réz szegecs-rudacskák. Mivel a lapok mérete a merevebb borítóénál kisebb ezért az 1937 M magyar útlevelet kell az első könyvecske kialakítású úti okmánynak tekinteni. A kezdeti változat borító módosulatai kissé alább kerültek ismertetésre.

A könyvkötészeti eljárások közül általános volt a lapok egymáshoz rögzitésekor a tüzökapcsos megoldás, a füzöszállal varrt kivitelezés ritkábbnak számított; azonban még ritkán, de elöfordult amár ekkor is elavultnak számitó és könnyen megbontható - zsineggel öltés is. A varrt okmányok közül a félig rejtett gerincöltés volt a gyakori, elsösorban a Brit Nemzetközösség tagállamai alkalmazták az oldalvarrást. Ritkának számitott hogy az okmányt nem tüzték és nem füzték, hanem harmonika szerüen hajtogatott (leporelló), a belsö felületén ragasztott lapból gyártották, igy az egyes lapoldalak két rétegböl álltak össze, ezt alkalmazta Olaszország, Románia és Törökország is.

A lapok (magas)nyomtatással történö sorszámozása gyakori volt, de nagyobb részben még továbbra is bármiféle sorszámozás nélküli megoldást alkalmazták (utóbbi megoldás hátránya, hogy egy adott lap nem volt egy adott okmányhoz köthetö, igy azt lapcserével könnyen felhasználhatták másik útlevélben). A szöveges lyukperforálás (ország-megnevezés vagy annak röviditése) nem volt gyakori, az okmány egyedi sorszámával történö perforálás rendkívül ritka volt (a hollandok és a magyarok alkalmazták ${ }^{64}$ ). Egyedi és elönyös megoldást alkalmaztak az argentin útlevelek esetében, annak lapjait a megszemélyesitést követöen csillagminták között okmányszámmal lyukasztotta ki a kiállitó hatóság, így a beragasztott fénykép is magán viselte a részleteit. Szintén ritka megoldás volt (csehszlovák és román okmányok esetében alkalmazták), hogy a lapoldalt sorszámbélyegzővel sorszámozták és egyúttal a füzet lapjait az országot jelölő szóval / röviditéssel lyukasztották.

Az 1937 M magyar útlevél ürlapok borítójának ,útlevél” szavainak kialakítása 1938-től kezdődően már az előre nyomtatott tartalmi változás bevezetése előtt - eltérő betűkkel készültek: vastagabbak lettek, valamint elsősorban az „Ú”, az „A”, az „S” és az „R” betük eltérnek a korábbi kialakítástól. Az 1939-es nyomdai jelzettel legyártott nagy mennyiségü útlevélfüzetnek csak egy kisebb részét kötötték be, a fennmaradó részt csak a későbbi évek során látták el borítóval, ahogy az fentebb is ismertetésre került. Az 1683/1939. nyomdai jelzetü igen magas sorszámúak ${ }^{65}$ esetében az 1943 tavaszán készre gyártott példányok egy részének borítónyomatai a korábbiakhoz képest is további eltéréseket mutat (1937/1943B M magyar útlevél). A címer rajzolatában több kisebb változás történt: a címerpajzs baloldali mezejének vörös sávjait felülről szegélyező vékony vonal kissé távolabb helyezkednek el, a cserfa- és olajág alkotta koszorú levelei valamelyest eltérő vonalvezetésüek és a levelek erei vastagabbak, ezáltal nem illeszkednek egymáshoz oly’ szorosan mint korábban. Az állammegnevezés kialakításában eltérő betüfajta figyelhető meg: a magyar szöveghez képest a francia szavak betüi kissé alacsonyabbak; továbbá az „Á” betűk ékezetei hosszabbak és az alapbetűtől távolabb helyezkednek el, az „R" betük kissé szélesebbek, illetve az „O” betük enyhén lapítottak. ${ }^{66}$ Feltehetően a betü- és címermódosított borítóváltozatú ürlapok csak néhány ezres példányszámban kerültek legyártásra, mivel ezen nyomdai jelzetủek vagy még a szabvány címerképpel és betủkkel, vagy 1945 közepétől új elren-

\footnotetext{
* Glosszárium
} 
dezéssel és szöveggel, de a kezdeti nyomófelület alapján készültek. Az 1943-as illetve az 1945-ös borítóváltozatok (1937/1943B M illetve 1937/1945 M magyar útlevél; utóbbi részletezését lsd. alább) nem egymást követő sorszámcsoportból kerültek ki, s már az előbbi típust megelőzően a gyári szám szerint az időrendiség folytonossága megszünt. ${ }^{67}$ Az 1945-től alkalmazott, új borítókkal és felülragasztásokkal forgalomba hozott útlevelek külön részben kerülnek tárgyalásra, mivel ezek az alaptípusok / változatok félig vagy egészében készre gyártott ủrlapok utólagosan módosított változatai.

Az 1937 M magyar (magán)útlevél mellé 1940-ben szolgálati útlevelet vezettek be a „hivatalosan kiküldött közszolgálati alkalmazottak és az állami érdekből utazó magyar állampolgárok részére". ${ }^{68}$ Ezen hivatalos útlevél kiállító hatósága a Magyar Királyi Belügyminisztérium V/b. osztálya volt, amelyet a különböző minisztériumok elnöki osztály vezetőinek illetve helyetteseinek kérelmére állították ki. Az okmány megegyezett az 1937 M magyar útlevélürlap 1683/1939. jelzetủ változatával, azonban a borító színe sötétkék, müanyaggal bevont, bőrhatású mintázattal préselt vászon volt és azon „SZOLGÁLATI ÚTLEVÉL” / „PASSEPORT DE SERVICE” felirat eltérő betütípussal volt olvasható. Az okmány 1. oldalán az „SZOLGÁLATI ÚTLEVÉL.” / „PASSEPORT DE SERVICE.” szavak kerültek elhelyezésre két sorban, függőleges, kettős vonallal elválasztva, ezáltal a címer és a terjedelem megjelölése feljebb került; díjkategóriát jelölő római számot nem helyeztek el, azonban csak 50 filléres bélyegképpel készült; az itt olvasható állammegnevezés magyar szövegét pont zárja. A 3. oldalon ezúttal kialakított „utazás célja” rovat tartalma, amely előre nyomtatva, kitöltve lett kialakítva: „állami kiküldetés.” illetve „mission officielle.”, akárcsak a kiállító hatóság megjelölésére szolgáló rovatban is dőlt betűkkel, eltérő betütípussal a „M. kir. Belügyminiszter.” illetve „Ministre Royal Hongrois de l'Intérieur" szavak. A 44. oldalon elhelyezett figyelmeztetés szövege csak 2 bekezdésben 5 sor terjedelmü volt, a 1937 M magyar (magán)útlevélhez képest nagyobb betủmérettel és arányaiban kissé nagyobb sortávolsággal.

Az 1937 M magyar (magán)útlevélnek ismert helyi gyártású változata is. A berni magyar követség a háborús idők és a fokozódó utánpótlási nehézségek miatt a forgalomban lévő magyar útlevél másolatát gyártotta le 1945-ben (1937/Bern M útlevélürlap), amelyet a Svájcban székelő magyar külképviseleteknél beadott útlevélkérelmek teljesítésekor, új útlevelek kiadásához használták fel. Ezen okmányürlapok, az igénybe vehető alapanyagok, nyomdai berendezések és megoldások miatt több szempontból is eltérőek. A borítója középzöld színű vászon, amely szövegnyomata az alaptípushoz viszonyítottan nagyobb sortávokkal került kialakításra. Az okmány lapjai vízjel nélküli papír, a magasnyomtatással készített zöld alnyomata kevésbé erőteljes, de a mintázata szinte azonos a korábban Budapesten készültekével. Az 1683/1939. nyomdai jelzetü útleveleket alapul vevő elörenyomtatott szöveg az alap-ürlappal közel azonos betütípussal készült, a szövegek szedésében azonban több eltérő kivitelezéssel, ${ }^{69}$ I. díjkategória-jelöléssel, de az illetékbélyeg képe nem lett rányomtatva, helyette fél kerettel határolták a beragasztandó bélyeg helyét. A fénykép rögzítéséhez nem alakították ki a szegecs-rudacskát tartalmazó egyszerü szerkezetet, és a képmást egyszerü gyürükapoccsal sem rögzítették. A lapok füzéséhez vastagabb füzőszálat, sürübb öltéssel alkalmaztak; a lapokat nem perforálták a gyári számmal, helyette magasnyomású sorszámot helyeztek el minden oldal felső részébe, ami miatt az oldalszámot áthelyezték alulra. A nyomdai jelzet eltérő betütípussal és helyesírási hibával („Követseg”) készült, a gyári számot mellette nem tüntették fel. Ebből az okmányürlapból ismert gyári szám „№ 000079” - amelyet a zürichi magyar főkonzulátus 1945. VII. 30-án állított ki és ezt követően az okmányra jogosult fel is használt tartózkodása során -, azonban a legyártott mennyiség meghaladta akár a több százat is. ${ }^{70}$ Nem zárható ki, hogy a párizsi magyar külképviselet is készítettet saját készletet ezen útlevéltípus alapján.

\section{Az 1937 M magyar útlevél megszemélyesítésének védelmi jellegzetességei és összehasonlítása}

Az 1937 M magyar útlevél kiállítása 1937. III. 1-én kezdődött meg, amelyet csak 1940 novemberétől követet a szolgálati útlevelek kiadása. A korábbi útlevelek még érvényben maradtak, de meghosszabbítani azokat már nem lehetett, s így az érvényességük legkésőbb 1938 február végén lejárt. ${ }^{71} \mathrm{Az} 1937 \mathrm{M}$ ürlapok utolsó ismert magyarországi kiállítási dátuma 1948. II. 12., amely 1937/1943B M borítóján és címoldalán is egyaránt nyomdai felülragasztott útlevél volt, s kivándorló részére személyesítették meg (ellenben az 1948 M magánútlevél ${ }^{72}$ első ismert kiállítási dátuma 1948. I. 15.).

A Magyar Királyi Állami Nyomda által legyártott és raktározott útlevélưrlapokat a kiállító hatóságoknak ${ }^{73}$ - a pénzügy- és belügyminiszter hatályos rendelkezésében meghatározottak szerint - egyénileg kellett igényelnie és beszereznie a nyomda igazgatóságától, a bélyegilleték összegét pedig előre meg kellett téríteniük. ${ }^{74}$ A magyarországi kiállító hatóságok már 1936 december elején megkapták a mintaokmá- 
nyokat „a hozzátartozó fénykép megrögzítő lemezkékkel együtt”, amelyek révén az illetékes személyek megismerkedhettek az új ürlaptípussal és sajátosságaival; ezekből a Magyar Királyi Rendőrség Budapesti Főkapitánysága tíz darabot kapott. ${ }^{75}$

Az útlevélürlap megszemélyesítése során - azaz az okmány birtokosának személyes adataival történő kitöltéséhez - továbbra is az 1922-ben kiadott belügyminiszteri körrendeletet kellett a kiállító hatóságnak követni. ${ }^{76} \mathrm{Az}$ egyes útlevelek kiadását a kiállító hatóságok vezetője vagy kijelölt helyettesei hagyták jóvá, az útlevélürlapok kitöltését általában az erre kijelölt ügyintézők végezték. A rovatok kézzel történő megszemélyesítése során különleges összetételü - ún. vasgallusz ${ }^{*}{ }^{77}$ fekete, Günther Wagner-féle Pelikan „Allwetter-Tinte” csekktintát alkalmaztak, amely a magyar útlevél lapjába megfelelően szívódott be és szinte eltávolíthatatlan volt. ${ }^{78}$ A magyar és francia kétnyelvü kitöltésnél az alkalmazandó magyar kifejezéseket és azok pontos francia nyelvü fordításait vagy megfelelöit útlevél szakszótárban ${ }^{79}$ tette közzé a Belügyminisztérium, amely tartalmát - szükség és igény szerint - esetenként módosították, kiegészítették. ${ }^{80}$ A belügyminiszter 1935 májusában leiratban ismertette az egységes, titkos jelzéseket, amelyeket a magyar külképviseleti hatóságok az ,államrendészeti szempontból aggályos” - megfigyelendő vagy elóállítandó - magyar állampolgárok úti okmányainak megszemélyesítése vagy meghosszabbítása során alkalmazott, ezzel segítve elő a határforgalmat ellenőrző magyar hatóságok ellenőrzéseinek hatékonyságát. ${ }^{81} \mathrm{Az}$ útlevél kiállítását hitelesítő vezető tisztviselő az első belső előzékre vezette fel aláírását, és mellé helyezte el nedves-bélyegzőlenyomatát illetve több hatóság esetében a fényképre is; ${ }^{82} \mathrm{az}$ 1. oldali illetékbélyeg-képet szintén a körbélyegző nedves lenyomatával „érvénytelenítették” (ez alól kivétel például a Magyar Királyi Rendőrség, ahol az útlevelek kiadása során általában külön, dátumsorral ellátott bélyegzővel tették ezt).

A vonatkozó rendelet értelmében a fényképnek lehetőség szerint $5 \times 7 \mathrm{~cm}$-nek kellett lennie, a kiállító hatóságnak élethủ képmásokat lehetett befogadni, s amennyiben közös útlevelet kérelmeznek (házaspárral vagy családdal), akkor, lehetőség szerint „,közös fényképet kell bekívánni”. ${ }^{83} \underline{A}$ fénykép rögzitése és biztositása a korábban alkalmazotthoz képest meröben új módszerrel történt. Az útlevélürlap első fedőlapjának belső felén, a kötészet során kialakított, rejtett fém lapra forrasztott két, kúpos fejủ szegecsrudacskára felszúrták a fényképet, majd egy-egy címer alakú mủanyag alátétet illetve rá tízágú csillag alakú lapkát helyeztek. A magyar állami címert (a magyar Szent Korona ferde keresztje nélkül) ábrázoló müanyag alátét átlátszó színtelen, zöld, olajzöld, kékeszöld vagy kék színű volt, ${ }^{84}$ mérete $11 \times 18 \mathrm{~mm}$. Gyakrabban előfordult, hogy a címerlapkákat fordítva, hátlappal felfelé helyezték el, ${ }^{85}$ de igen ritka volt, hogy egy okmányban két eltérő színárnyalatú címerlapkát alkalmaztak. A tízágú, csillag alakú, bronzzal futtatott vasból készített lapkáknak minden második ága volt karommal ellátva. A fénykép-alátétcsillaglapka rétegezést követően különleges szerszám, ún. szegecsprés alá helyezték az okmányt, amely a szegecs-rudacskák végét lapítva lyukat mélyesztett, ez által azok a fém csillagokhoz feszültek, egyúttal a csillagokat lefelé nyomva, annak karmait a müanyag alátétbe mélyesztették. Ennek lényege az volt, hogy a legyártott okmányürlap már eleve tartalmazta a fényképrögzítő eszközt (a szegecseket), így a fénykép érdemi, minőségủ cseréjéhez az okmány szerkezetét is meg kellett bontani. A müanyag alátét előnye abban rejlett, hogy egyrészt az okmány kiállítását követően szerves részévé tett egy - a papír, a vászon és a füzőszál mellett - további alapanyagú részletet; másrészt ezen vékony lapkák a karmos kapcsok felfeszítése során sérülhettek vagy torzulhattak.

A fénykép hitelesítésének eloírt eszköze a kiállító hatóság - fényképet és belső elözéket is érő szárazbélyegzö-lenyomata volt, ${ }^{86}$ azonban számos hatóság szintén érintőlegesen elhelyezte a nedvesbélyegzőlenyomatát is (ez jelentősen növelte a fényképcsere felismerésének lehetőségét). Az arckép útlevéllapra történő ragasztására vonatkozó elöírást - amelyet ezen útlevélnél a legtöbb kiállító hatóság már nem alkalmazott - a belügyminiszter 1937. X. 29-én kelt körrendeletével megszűntette; ${ }^{87}$ ezáltal a határforgalmat ellenőrző hatósági személy olvashatta a képmás hátoldalára előzetesen felvezetett tartalmat (az ábrázolt személy neve, születési adatai, stb.). A fényképet, annak elő és hátoldalán az ábrázolt személynek alá kellett írnia, amelyet - az útlevélürlap hatóság általi kitöltését követően - a fénykép alatt, az erre a célra kialakított felületen meg kellett ismételnie; gyakorta előfordult, hogy a kiállító hatóság nem íratta alá a fénykép elöoldalát és / vagy a fénykép alatt a megfelelő rovatot.

A megszemélyesités során a kézirással történö kitöltés általános volt a vizsgált államok okmányai esetében, igen ritkának számított az irógépi kitöltés (ezt csak az Amerikai Egyesült Államok és Kanada alkalmazta). A fényképek rögzitését néhány ország gyürükapcsokkal is állandó jelleggel kiegészitette (a román okmányok elsö belsö elözékén elhelyezett fényképeket négy félig rejtett kapocs rögzitette),

\footnotetext{
* Glosszárium
} 
azonban még sok ország kiállitó hatóságai gyakorta csak eseti jelleggel alkalmaztak gyürüs- vagy tüzökapcsos kiegészitést. A száraz- és / vagy nedves-bélyegzölenyomattal történö fénykép-hitelesités általános volt, amely közül az Amerikai Egyesült Államok útlevélhatóságainak megoldása emelkedett $k i$, ahol a címeres száraz körbélyegzö mellett alkalmaztak háromsoros szöveges szárazbélyegzölenyomatot, amelyet két szinnel (pirossal és kékkel) festettek meg még a préselést megelözöen.

A kiállító hatóságok illetékességi területén igen eltérő számú népesség élt. A leggyakoribbak a Magyar Királyi Rendőrség Budapesti Főkapitányság Útlevél Osztályán ${ }^{88}$ kiállított útlevelek, amely hatóság az ország legnagyobb ügyforgalmát bonyolította le, ${ }^{89}$ az országos új útlevélkiadásnak 54-60 \%-a ott történt (a meghosszabbításokkal ennél nagyobb arányban vették ki a részüket), 1937 június havában átlagosan napi 800 okmányt (!) személyesítettek meg ${ }^{\mathbf{9 0}}$. Igen ritka a kis számú, és elsősorban a kettősbirtokos és / vagy kishatárforgalomban részt vevő lakossággal rendelkező Csanád, Arad és Torontál, valamint Szatmár, Ugocsa és Bereg közigazgatásilag egyelőre egyesített vármegyék, illetve Bács-Bodrog vármegye alispánjai által kiállított magyar útlevél. A külképviseleti kiállítások közül általában azok tekinthetőek igazán ritkának, ahol csekély számú útlevél-ügyforgalmat rögzítettek, ide elsősorban azon m. kir. konzulátusok tartoztak, amelyeknek székhelyének otthont adó államban kevés magyar állampolgár fordult meg, vagy az - az 1937 M magyar útlevél kiállítási időtartamán belül - csak részlegesen müködött. A kiállított útlevelek száma alapján kiemelkedik az 1937. év, mivel - a belügyminiszter akkor már két éve nem engedélyezte egy évnél hosszabb időre kiállítani vagy meghosszabbítani az útleveleket, illetve 1937. március 1-jétől kötelezően az új ürlapot tölték ki - közel három és félszeresére ugrott az új útlevelek száma és utána következő két évben is a korábbi másfél-kétszerese maradt. A kiállított útlevelek számában az 1940-es visszaesést az Európában kibontakozó II. világháború miatt hozott korlátozó intézkedések és a szigorodó külföldi vízumszabályok eredményezték. Az 1941. év jelentős növekedése a visszacsatolt Észak-Erdély eredményezte lakosságnövekedés és -összetétel miatt is történt (ekkor összesen 2.460 .000 fővel, azaz 20 \%-kal nőtt Magyarország lakossága, e lélekszámból 1,07 millió volt román nemzetiségü, akik közül gyakorta a délen maradt kapcsolataik fenntartása okán igényeltek úti okmányt). A terület-visszacsatolások miatt átrendeződő ügyforgalmakat jól mutatja, hogy a Magyar Királyi Rendőrség Budapesti Főkapitányság Útlevél Osztályának országos összesítésben 1939-ben, majd a rákövetkező évben jelentősen csökkent a szerepe: csak $42 \%$-át adták ki az összes új útleveleknek (ez részben a visszacsatolt Felvidék és Kárpátalja hatása volt), $\mathrm{s}$ a részesedés 1942-ben, a vidéki útlevélhatóságoknál megugró számok miatt tovább csökkent.

Megemlítendő, hogy már az 1937 M magyar útlevelek bevezetését követően, 1937 május végén a Magyar Királyi Belügyminisztérium V. (igazgatásrendészeti) osztálya foglalkozni kezdett az új úti okmányok meghamisítás felismerésének növelésével. Ezért már 1937. VI. 3-án az említett osztály értekezletet tartott, amelyen a Magyar Királyi Rendőrség részéröl GöMBÖs László rendőr tanácsos, a budapesti fókapitányság útlevélosztályának vezetője és PUSZTASZERI Ferenc rendőrségi szakértő vett részt. ${ }^{91} \mathrm{Az}$ elképzelés szerint az útlevelet „ellenőrző lapokkal”, de pontosabban ellenőrző oldalakkal látták volna el, amely tartalmazná a jogosult személyes adatainak egy részét betü- és számtábla megfelelő lyukasztása révén. ${ }^{92}$ A Magyar Királyi Rendőrség szakértői részére - a lefolytatandó kutatások céljából - nyolc mintaokmányt biztosított a belügyi tárca. ${ }^{93}$ Azonban a szakértői vélemény szerint az 1937 M magyar útlevél kizárja a „tökéletes meghamisítás lehetőségét”, így alkalmazását nem javasolta, valamint a név-lyukasztás elkészítéséhez becsült 1,5-2 perc igen nagy időráfordítást eredményezne a nagy ügyforgalmat lebonyolító kiállító hatóságok részére. Szintén a bevezetés mellőzését támasztotta alá, hogy a rendelkezésre bocsátott nyolc mintaokmányon sürün voltak a betük és számok, így a kötészet során kissé eltolódó nyomatfelületek miatt nem biztosított eléggé, hogy a lyukakon keresztül a valós név jelenik meg, esetenként csak egy eltolódott betücsoport lenne látható. ${ }^{94}$ A Magyar Királyi Belügyminisztérium végül elállt az ilyen irányú további újításoktól.

\section{Az 1937 M magyar útlevél felülnyomatai és kiállításának hibái 1945 után}

A magyar útlevélhatóságok a harci események közeledtével is müködtek. Az útlevél-kiállítás és meghosszabbítás, továbbá a kiutazások engedélyezése a magyarországi frontvonal fokozatosan nyugat felé húzódásával sem állt le. ${ }^{95}$ Eközben 1944. XII. 22-én Debrecenben megalakult a magyar Ideiglenes Nemzeti Kormány, ezáltal a magyar közigazgatás - a hadi események mủveleti határai mentén - két részre szakadt. Az Ideiglenes Nemzeti Kormány közigazgatási intézményei kezdetben elfogadták a korábban kiállított útleveleket és azokat meg is hosszabbították. ${ }^{96}$ A belügyminiszter 1945. VIII. 21-én kelt rendelete értelmében a magyar államhatárt magyar állampolgár már csak érvényes, 1945. V. 1-je után kiállított vagy meghosszabbított útlevéllel lehette át. ${ }^{97} \mathrm{E}$ rendelet szigorát 1947. I. 10-től némileg enyhítették, így nem kellett kiutazás előtt az útlevélhez jóváhagyási zára- 
dékot igényelni, azonban ezen kiegészítés nélkül csak az 1945. V. 1-je után kiállított útlevéllel lehetett utazni. ${ }^{98}$

A magyar közigazgatásban 1945 tavaszán bekövetkezett változás a királyság államforma felülvizsgálatát is magával vonta, hamarosan megkezdődött az útlevelekben szereplö, királyságra utaló elöre nyomtatott szövegrészek hatóság által történt kihúzása / kitakarása, államforma-semleges változatban. ${ }^{99}$ Mindeközben már 1945 nyarának legelején a Belügyminisztérium - „Magyarország közjogi berendezésének" átszervezéséhez kapcsolódóan - egy külalakjában és tartalmában is a korábbihoz képest eltérő, új útlevél gyártását és bevezetését tervezte, ${ }^{100}$ azonban még két és fél évnek kellett eltelnie egy új útlevélürlap bevezetéséig. A Magyar Köztársaságot 1946. II. 1-jén kiáltották ki, ezt követően az 1937 M útlevelek királyságra utaló szövegrészét szintén törölték / felülragasztották és az új megnevezés jelölését kezdték meg. Az 1937 M magyar útlevélürlapok új igényeknek megfelelő módosításának három változata ismert, amelyből az első az útlevélfüzet-készlet új borítóval történő ellátása során keletkezett, a másik kettő esetében a korábbi útlevélürlapok kész példányait módosították.

A borító nélkül raktározott útlevélürlap-füzetek készleteinek felhasználása úgy történt, hogy azokat már egy új boritóra ragasztották, ez az 1683/1939. jelzetü nyomtatványokat érintette (1937/1945 M magyar útlevél). Az új borító a korábbiaktól eltérő tartalmú arany színú fólianyomattal rendelkezik, amely gyártása 1945 tavasza után, de még 1946 februárja elött megtörtént. ${ }^{101}$ A fedőlapon a koszorúval övezett koronás kiscímer (általános címerkép) feljebb került elhelyezésre, amely alá a „MAGYARORSZÁG” és „HONGRIE” szavak lettek nyomtatva; a korábbi „Magyar Királyság Royaume de Hongrie” szövegeket már nem alakították ki az „útlevél” szó felett. Korábban az állammegnevezést tartalmazó felületet - a legyártott, de forgalomba még nem hozott ürlapok borítóira; a köztársaság kikiáltását, 1946 februárját követően - szabványos, de egyszerủ kivitelủ téglalap alakú karton lappal felülragasztották, amelynek tartalma „MAGYAR KÖZTÁRSASÁG” „REPUBLIQUE DE HONGRIE” kétsoros felirat volt. Az első oldal módosításában ritkább előfordulással készült a - fentebb ismertetett lapoldal-részlet nyomtatásával-felülragasztásával történő kitakarás, illetve az általánosabb esetben vastag sáv alá kialakított „MAGYARORSZÁG HONGRIE” szavakkal, fekete színnel nyomdai úton felülnyomtatták, oly módon, hogy a korábbi állammegnevezés egészében kitakarásra kerüljön. A negyedik oldal „kir.” illetve „royales” szövegét, akárcsak a negyvennegyedik oldal nyomdai jelzetének „kir.” rövidített részletét fekete, téglalap felületekkel nyomdai úton takarták el.

Az új államforma 1946 februári kikiáltását követően a korábbi évek - megszemélyesített vagy kitöltetlen - útlevélürlapjait a változásnak megfelelően módosították. ${ }^{\mathbf{1 0 2}}$

1, A korábban kiállított útlevelek meghosszabbításakor a kiállító hatóság a borítón található „Magyar Királyság Royaume de Hongrie” feliratot téglalap alakú nedvesbélyegzővel letakarta és fölé azonos tintával „MAGYAR KÖZTÁRSASÁG” „REPUBLIQUE DE HONGRIE” tartalmú kétsoros feliratot bélyegzett. Az első oldal állammegnevezését széles téglalap-bélyegző segítségével egészében takarták ki, ritkábban tollal kihúzták a királyságra utaló szövegrészt és a magyar nyelvüt „ország” szó hozzáadásával egészítették ki. ${ }^{103}$ (Ezen okmányürlapok nem altípusok / alcsoportok, mivel a kiállítást követően módosították azokat.)

2, A készleten maradt, borítóval már ellátott útlevélürlapok nyomdai úton történő felülbélyegzése / felülcímkézése elsősorban az 1683/1939. jelzetű útlevélürlapokat érintette (1937/1938-F M magyar útlevél). A borítón található „Magyar Királyság Royaume de Hongrie” feliratot téglalap alakú karton lappal felülragasztották, amelynek tartalma, két sorban „MAGYAR KÖZTÁRSASÁG” „REPUBLIQUE DE HONGRIE” volt. Az első oldal állammegnevezését korábbi útlevelekből vágott csíkkal ragasztották felül, amelyre azt megelözően, fekete színnel rányomtatták vastag sáv alatt a „MAGYARORSZÁG HONGRIE” feliratot. A negyedik oldal „kir.” illetve „,royales” szövegét gumibélyegzők segítségével letakarták, akárcsak a negyvennegyedik oldal nyomdai jelzetének „kir.” rövidített részletét. Ilyen útlevélürlap még 1947. augusztus 5-én is megszemélyesítésre került. ${ }^{104}$

A II. világháborút követően jelentős változások történtek az útlevél-kiállitás területén is, 1945 júliusának elején a magánútlevelek tekintetében kizárólagos útlevélhatóságként a Magyar Államrendőrség területileg illetékes főkapitányságának vezetöit kijelölték ki. ${ }^{105}$ Azonban útlevelet „csak kivételesen és indokolt esetben", a belügyminiszter elözetes engedélye után lehetett kiállítani. ${ }^{106}$ Az útlevél-kiállítás illetéke - a pengő egyre gyorsabb ütemű inflálódása miatt - mind gyakrabban változott, ennek megfelelően az útlevélbe az illetékbélyeg(ek)et közvetlenül a megszemélyesítést megelözően ragasztották be és felülbélyegezték. ${ }^{107} \mathrm{Az}$ első hónapokban, több esetben is szabálytalanul lettek az útlevelek kiállítva, előfordult, hogy „francia szöveg nélkül, helyesírási hibával, szabályellenesen leragasztott fényképpel, fényképrögzítő kapocs és ez alá helyezendő címer nélkül, közönséges ringlivel felerősítve, lebélyegzés nélkül" adtak ki úti okmányt. ${ }^{108}$ A belügyminiszter 1945 novemberében engedélyezte, hogy a szüksé- 
ges egyedi prés hiányában, a szegecs kialakítását „kalapáccsal is el lehet végezni”, ez esetben szárazés nedves-bélyegzőlenyomatának egyidejü alkalmazása is kötelező volt. ${ }^{109}$ Azonban a kiállítás során továbbra is számos esetben mulasztásokat követtek el a kiállító hatóságok (leragasztották, szegecselték a fényképet, vagy azt nem íratták alá az ábrázolt személlyel, francia helyett az utazás szerinti ország nyelvén töltötték ki az okmányt, stb.), ezért a belügyminiszter 1946 szeptember végén ismét a szabályok betartására utasított újabb rendelete útján. ${ }^{110}$ A megszemélyesítés során - igazodva az új államforma új címeréhez - az 1946-tól kiállított útleveleknél a mủanyag címer lapkákról levágták a magyar Szent Koronát (általában a korona alsó abroncsa visszamaradt), ritkán de előfordult ennek a változtatásnak hiánya is. Az útlevélhatóságok köre tovább szükült, 1946 utolsó napjaiban a belügyminiszter rendelete értelmében magánútlevelet kizárólag a Magyar Államrendörség Budapesti Főkapitánysága volt jogosult kiállítani vagy meghosszabbítani; az útlevél kérelmezésének alapját tovább szúkítették, de a belügyminiszter előzetes jóváhagyása már nem kellett Európa legtöbb országába szóló úti okmány esetében. ${ }^{111}$

Az 1937 M útlevélürlapoknak ismert az 1945 utáni magyarországi közigazgatás szabályaitól független megszemélyesitése illetve meghosszabbítása is. Az 1944 végén megalakult magyar Ideiglenes Nemzeti Kormány, majd a köztársasági és népköztársasági kormányzat számos olyan állammal nem vette fel a diplomáciai kapcsolatot, amellyel korábban fennállt, ennek elsősorban a politikai változás volt az oka; így Spanyolországgal és Portugáliával sem állt helyre a kapcsolat. A lisszaboni magyar konzulátus az időközben megszűnt „királyi” Magyarország diplomáciai képviseletét továbbra is ellátta, BAJÁN Artúr konzul - e tisztében és ezen állomáshelyén 1938 júliusától dolgozott, a köztársasági magyar kormány csak 1948 februárjában mentett fel a szolgálat alól - a magyar úti okmányok (köztük diplomata útlevelek) meghosszabbítását folytatta, bár azokat a SALAZAR vezette Portugálián kívül más állam általában csak úgy fogadta el, ha ezen ibériai állam tartózkodási engedéllyel látta el. ${ }^{112}$ A madridi magyar követség 1949 márciusától, miután a spanyol kormány átadta a korábbi külképviselet épületét - a spanyol fővárosban 1946 tavaszától már félhivatalosan dolgozó MAROSY Ferenc vezetésével - a magyar érdekek és a magyar királyi közigazgatás képviseletét látta el; ezt a spanyol kormányzat tudomásul is vette. MAROSY a követség épületének átvételekor „nagyobb mennyiségü biankó útlevelet" és a hitelesítésre használt bélyegzőket talált, amelyek felhasználását megkezdte új okmányok kiállítása illetve régiek meghosszabbítása során. ${ }^{113} \mathrm{~A}$ hivatala által hitelesített / érvényesített útleveleket és „Hazatérési Igazolványokat” több állam - köztük Portugália, Olaszország, Svájc és több dél-amerikai állam - hatósága is elismerte érvényes úti okmányként és azokba vízumot adott. ${ }^{114}$ A madridi magyar külképviselet vezetője tíz évig érvényes diplomata útlevelet is kiállított egy korábban hivatalban lévő, immár emigrációban élő magyar királyi követ részére. ${ }^{115}$ Értelemszerüen mindkét „külképviseleten” érvényesített „magyar királyi” úti okmányokat a magyar kormányzat és az azzal baráti kapcsolatokat ápoló államok nem fogadták el, így azok Magyarországra történő (haza)utazásra nem voltak érvényesek. Magyarország és Portugália között 1974 nyarán, Spanyolországgal 1977 elején álltak helyre a diplomáciai kapcsolatok, azonban a lisszaboni „magyar királyi” külképviselet az 1950-es évek végétől már nem müködött, a madridi pedig - a spanyol kormány szocialista államok felé nyitása miatt - 1969-ben szűnt meg. ${ }^{116}$

\section{Kritikák és észrevételek}

Az 1937 M magyar útlevélnek nem lenne teljes az ismertetése és összehasonlítása, ha a többi ország esetében alkalmazott útlevélgyártási eljárások alapján nem lennének megfogalmazva kritikai észrevételek is. Fokozta volna a hamisítás elleni védelmet, ha az okmány vízjele két árnyalatú kialakítással (esetleg ábrával együtt) készül. A különböző vegyi anyagok hatására az alnyomathoz alkalmazott zöld festék nem folyt szét, az okmánypapír a savakra és lúgokra eltérő módon reagált, azonban nem minden esetben színeződött el jelentősebben. ${ }^{117}$ Szintén további előnyt jelentett volna, ha a magasnyomtatás mellett más nyomtatási eljárásokat is alkalmaznak (például a bélyeggyártásnál ekkor általános rács-mélynyomtatást, vagy a bankjegyeknél nem nélkülözött metszett mélynyomtatást), bár a nyomtatási technikák párosítása útlevelek esetében még nem volt jellemző ezen korszakra; az alnyomat színének esetenkénti erőssége a halvány bélyegző-lenyomatok vizsgálatát kissé nehezítette. Az okmány gyártását követő megszemélyesítési eljárásnál további előnnyel járhatott volna, ha a száraz- és nedves-bélyegzőlenyomatot egyszerre és kötelezően alkalmazzák, és esetleg a szárazbélyegző pozitív felének kiemelkedő részét vékonyan festékezik (ez esetben e nyomó felület érintette volna a fényképet), valamint az okmány rovatainak kitöltéséhez - esetleg egyedi betúkarakterekkel rendelkező - írógépet használnak, amelyet az 1920-as évek eleje óta alkalmaztak a magyar diplomata útlevelek esetében. 
Az 1937-ben bevezetett magyar útlevélről a korszakban kritikaként fogalmazták meg, hogy a rovatok kitöltésére szolgáló része nem eléggé terjedelmes, valamint több ország vízumbélyegzője méreténél fogva alig volt elhelyezhető. Az útlevélürlap kötését egyes vélemények hanyagnak találták. ${ }^{118}$ A hivatalos rendőrségi állásfoglalás azonban a fénykép minőségi cseréjét nem tartotta megvalósíthatónak, s a különleges tinta miatt az adatok módosítását - látható jelek nélkül - szinte lehetetlennek ítélte. ${ }^{119} \mathrm{Az} 1937 \mathrm{M}$ ürlapon a megszemélyesítésre rendelkezésre álló helyek valóban keskenyebbek lettek, az oldal szélességének 21 milliméterrel csökkentése miatt, amelyek - különösen a naponta sok okmányt kitöltő tisztviselők esetén - gyakran a feleség adatainak fenntartott rész igénybe vételét jelentette, elsősorban a családi állapot, vallás és személyleírás rovatokban. A gyakorlatban a lapok szélessége megfelelő volt a Budapesten müködő magyar külképviseletek által alkalmazott vízumbélyegzö-lenyomatok elhelyezésére; még a legszélesebbek közé tartozó egyiptomi, francia, holland és lengyel külképviseleté is elfértek egy oldalon.

Az 1937 M magyar útlevél nem lett maradéktalanul ,a hamisítást a lehetőségig kizáró” okmány mint ahogy egyik sem volt az -, azonban elmondható róla, hogy korszakának egyik legjobbikának számított, bár egyes védelmi jellegzetessége fokozható lett volna, de az egységet tekintve élvonalbeli volt. A fénykép rögzítésének módja a fényképcserét nehezítette meg jelentős mértékben, az okmányban a jogosult többszöri aláírása szintén akadályokat okozhatott. (A korabeli, már 1933-tól kiállított, keményfedeles román útlevelekben az első belső előzéken elhelyezett fényképeket négy gyürükapocs biztosította, azonban ezekben a fényképcsere könnyebben kivitelezhető volt a ringlik körülvágásával, míg a magyar okmányokban az átlátszó müanyag lapkák mögötti fényképrészlet cseréje rendkívül nehéz volt, vagy csere híján könnyen észrevehető volt az új kép illesztése, a beavatkozás.) A lapok vízjele jól kivehető, látható volt, így a korszakban igen nehezen volt az utánozható, a füzet füzésének megbontása több sérüléssel is járt, a szinte egyedülállóan perforált sorszámú lapoldalak a lapcserét tették könnyen felismerhetővé. A gazdag és az egész oldalt fedő alnyomat, a hivatalos bejegyzések (megszemélyesítés; vízumok, átléptető-bélyegző lenyomatok, stb.) törlését, illetve a mintázat díszessége és rejtett eltérései az utánzást nehezítette meg.

Nem nélkülözhető azon észrevétel sem, hogy éppen az európai és a magyarországi vallási megkülönböztetések idejée ${ }^{120}$ kezdték meg azon magyar útlevél-ürlapok kiállítását (1939 tavaszától), amelyen a vallás rovat - és az utazás célja - már elhagyásra került. Mindez azok után történt, hogy - a németországi, majd az ausztriai izraeliták nagyszámú tömegeinek kivándorolása miatt - a franciaországi Évian-les-Bains-ben, 1938 júliusának elején 32 ország részvételével megtartott konferenciát követően sok állam elzárkózott a menekülők további befogadása elől. Svájc 1938 nyarától - az Anschluss-t követő izraelita közösséghez tartozó osztrákok nagyobb számú menekült csoportjai miatt - csak azzal a feltétellel tartotta fenn a németek vízummentességét, ha a zsidó vallású német állampolgárok útleveleire - a német kormányzat szándéka ellenére - megkülönböztetö jelzést bélyegeztek: vörös „J” betüt (a „Juden”, azaz „zsidó” német szó kezdőbetủjét; az 1. oldalon és gyakran a borítón is). ${ }^{\mathbf{1 2 1}}$

\section{Az 1937-ben bevezetett technikák utóélete}

Az 1937 M magyar útlevélnél kialakított adathordozó és érvényességi oldal-elrendezést az 1948 M magyar útlevélcsaládnál tovább alkalmazták, azonban az okmány már eltérő alnyomattal és vízjellel lett kialakítva. (Az 1950 M útlevélnél az alnyomaton, vízjelen túl az adatokat hordozó előre nyomatott szövegek elrendezését is átalakították; ezt az okmányt már a budapesti Pénzjegynyomda készítette. ${ }^{122}$ )

Az 1937 M magyar útlevélnél bevezetett fénykép-biztosítási eljárást (a tízágú karmos csillag alakú szegecseket mủanyag címer alakú lapka alátéttel) az 1948 M és az 1950 M magyar útlevelek esetében is alkalmazták; a mủanyag alátét használatát 1951 körül szüntették meg. Az 1953 M magyar útlevélnél már nem rögzítették lyukszeggel a fényképet, hanem már „,csak” ragasztották. Az 1945 után véglegesen központosított útlevélkiadás a kiállítási módokban tényleges egységesítést hozott, a fényképeket ezt követően száraz- és nedvesbélyegző lenyomatával egyaránt hitelesítették.

A félárú vasúti kedvezményre jogosító igazolványokat az 1940-es évek legelején kezdték el az 1937 M magyar útlevélnél alkalmazott fénykép-biztositási eljárással védeni (de itt tízágú helyett nyolcágú karmos lapkával kialakított szegecset müanyag címeralátéttel és szárazbélyegző lenyomatával a fényképen). A Magyar Államvasutak „közszolgálati alkalmazottak és családtagjaik részére" kiadott arcképes igazolványainak fényképrögzítése 1982-ig - az 1937-es útlevélnél először alkalmazott - karmos csillag lapkával kiegészített szegecsekkel történt, igaz nyolcágúakkal, s ekkor már régóta címer-alátét nélkül. ${ }^{123}$ 
Itt kell megjegyezni, hogy az 1937 M magyar útlevél borítójának olajzöld színét alapul véve, az 1992-ben bevezetett útlevélcsalád diplomata útlevelének borítójának - JESZENSZKY Géza akkori külügyminiszter kezdeményezésére - zöld színt határozták meg, ${ }^{124}$ amely azóta is alkalmazásban van.

Összességében az útlevelek egységesítésében az 1920-as elöírásokat 1927-ben követte újabb, ekkor a menekültek úti okmányaiét határozták meg. ${ }^{125} \mathrm{~A}$ hatalmas emberáldozatokat követelő II. világháború a menekültek még nagyobb és a korábbiaknál vegyesebb tömegét eredményezte. Az 1945-ben alapított - hamarosan a Népszövetség helyébe lépő - Egyesült Nemzetek Szervezete keretén belül 1951-ben egyezmény született a menekültek úti okmányának meghatározásával és leírásával, ${ }^{\mathbf{1 2 6}}$ majd az 1954-es hontalan személyek jogállásáról szóló megállapodás rögzített szabványos megjelenést és tartalmat, ${ }^{127}$ mindkettő az 1920 -as útlevél-elrendezés elvét követi a szükséges tartalmi módosításokkal.

A magánútlevelek ismételt egységesítését - más utazási elörások, mint a határellenőrzés és bejelentkezési kötelezettség témával egyidőben - tárgyalta a 1963. augusztus 21-e és szeptember 5-e között a Rómában, „Egyesült Nemzetek Nemzetközi Utazási és Turizmus Konferenciája” címmel 87 állam részvételével megrendezett értekezlet; azonban mindössze nem kötelező javaslatokat fogalmaztak meg, többek között az okmányok legnagyobb méretére és terjedelmére, valamint néhány általános alapkövetelményre vonatkozóan. ${ }^{128}$ Ekkorra már egyre több ország tért el az útlevélszabványtól, illetve - a nem-szocialista országok esetében - a növekvő határforgalom miatt annak gyorsabb ellenőrzése kívánt egységes kialakításokat, s az okmányhamisítás elleni védelem is követelményeket támasztott. Az 1920-as útlevélszabványt még több ország az 1970-es és az 1980-as években is alkalmazta, igaz méretében esetenként eltérő kivitelben. ${ }^{129}$ Hatvan év után, 1980-ban született ismét jelentős eredmény az útlevelek egységesítése területén, ekkor ezt már az Egyesült Nemzetek Szervezetének repüléssel foglalkozó szakszerve, a Nemzetközi Polgári Repülési Szervezet (International Civil Aviation Organization; ICAO) irányította, hiszen a légi közlekedésben az okmányellenőrzésre fordított idő terjedelme jelentős anyagi előnyt vagy hátrányt eredményez(het). Ezt követően a legtöbb ország az ICAO ajánlásait követve alakította ki útleveleit, azonban az újabb ajánlások alapján módosított okmányok bevezetése sok esetben csak évek múltán jelent meg. Kezdetben a gépi olvasásra alkalmas útlevelek egységes bevezetése volt a cél, ma már a legkorszerübb technikákban adnak ajánlást, egységes rendszert. Magyarország 1990 után törekedett a kor nemzetközi elöírásainak és igényeinek megfelelö útleveleket tervezni és gyártani, így került 1992. január 1jén bevezetésre az első, gépi olvasásra alkalmas magyar úti okmány, amely az ICAO akkori ajánlásainak is megfelelt.

Az Európai Közösség is törekedett a tagállamok útleveleinek egységes(ebb) megjelenésére. Az első közös szabályok 1981. június 23-án kerültek elfogadásra - többek között ekkor határozták meg az útlevél borítójának burgundi vörös színét és megjelenését, az oldalak tartalmát, stb. -, amelyet 1982, 1986 és 1995 nyarán, majd 2000 őszén és 2004 nyarán kiegészítettek. ${ }^{130}$ Az egységes müszaki elöírások körvonalazása 1982. június 30-án történt meg, amely ekkor még igen szerény követelményeket támasztott (például, hogy a lapok tartalmazzanak vízjelet, az okmány számát perforáció útján alakítsák ki a lapokon, stb.), ${ }^{131}$ ezt majd 2000 októberében pontosították és bővítették, ${ }^{132} 2004$ decemberében rendeletben a korábbiakat tovább részletezve, szabályozva már kötelező érvénnyel rögzítették ${ }^{133}$. A tagországok az aktuális elöírásoknak megfelelő első egységes megjelenésủ útleveleiket számos esetben csak évekkel a szabályok elfogadása vagy az Európai Közösséghez (majd Európai Unióhoz) történt csatlakozása után bocsátották ki. ${ }^{134}$ Magyarország az Európai Unió magánútlevelekre vonatkozó irányelveinek és rendeleteinek megfelelő úti okmányt 2006. augusztus 29-től állít ki.

\section{Jegyzetek:}

${ }^{1} 1723 /$ XII. tc. $1 . \S$.

${ }^{2}$ Így, többek között: az Amerikai Egyesült Államok, Argentína, Belgium, Brazília, Franciaország, a legtöbb német állam, itáliai államok, majd az egyesített Olaszország, a legtöbb svájci kanton és Svédország is.

A ritkább, de egységes jellegü külalakú útlevelet elsősorban Délkelet-Európa egyes kormányainak útlevélhatóságai állították ki, e kétoldalas, fektetett téglalap alakú okmányok első oldalát két, egyenlő oszlopba rendezték, amely közül az egyik a saját hivatalos, a másik francia nyelven tartalmazta az előre nyomtatott szövegeket és a kitöltendő rovatokat; az úti társak a hátoldal felső harmadában kerültek felvezetésre. Ezen okmányformát alkalmazta Románia (1860-as évekig), Törökország, Görögország és Egyiptom is a XIX. század középső harmadában és még azt követően is.

Eltérő kialakítású okmányokat alkalmaztak - más államok mellett - a brit, a dán, a holland, a kínai és az osztrák útlevélhatóságok. Sok ország útlevele csak néhány rovat kitöltendő felületén tartalmazott alnyomatot, de akadt számos állam, amely mindezt mellozzte.

Az 1877 előtt egy évtizeden keresztül alkalmazott - egységes tartalmú, de változatos megjelenésü - magyar útlevelek alnyomata igen aprólékos kidolgozottságú volt, az adatot hordozó első oldal felületének nagy részét fedte, a fejlécben elhelyezett állami címer finom kivitelü volt. 
${ }^{3}$ Ezen kialakítási formát belügyminiszteri rendelet határozta meg. DiENES ; 51 883/1877. (XII. 19.) BM.r.

${ }^{4}$ Ezen okmány legföbb eltérése az állami címer fajtája és azon belül is ábrázolásai, valamint az oldalak alnyomatának színe volt: ismert zöld, kék, piros és barna színnel nyomtatott változat.

${ }^{5}$ Füzet formátumú útlevelet állított a XIX. század utolsó évében Magyarországon kívül Németország (1868-tól; a Földön elsőként bevezetve), Ausztria (1879-töl), Oroszország és Bulgária illetékes hatósága is; Olaszországban 1901-ben, Romániában 1912-ben vezették be ezen kivitelezési, megjelenési formát.

Az I. világháborút követően vezette be a füzet / könyvecske kivitelezésü útleveleket, többek között Ausztrália, Egyiptom, az Egyesült Királyság (1921-től), a Dél-Afrikai Unió, Japán (1924 után), Kanada (1921-től), és az utolsók egyikeként Argentína, Belgium (1926 után), Görögország (1926-tól), az Amerikai Egyesült Államok (1927-től) és Franciaország (1928tól).

${ }^{6}$ A magyar Országgyülés 1903. január 13-ai, 182. ülésén gróf WILCZEK Frigyes képviselő - hivatkozva az útlevélben szereplő személyleírás túlzottan általános, több emberre is illő megfogalmazására - indítványozta, hogy az útlevél kötelező része legyen a fénykép. BORNEMISSZA Lajos képviselő felszólalásában felhívta a figyelmet, hogy a világon egyedülállóan a magyar útlevélben elhelyezendő arcmás alkalmazásával nehogy „oly intézkedést teremtsünk, amely az útlevélrendszert egész Európában, tehát a nemzetközi forgalomban megváltoztatja”. SzÉLL Kálmán miniszterelnök az útlevelek fényképpel történő ellátásáról szóló indítványra reagálva közölte, hogy az megvitatásra került már a közigazgatási bizottságban, ahol úgy találták, hogy „....ne nehezítsük meg az útlevelek kiadását ilyen formalitásokkal. Ha már egyszer ki akarjuk valakinek adni [ti.: az útlevelet], ne kössük fölösleges nehézségekhez. ... Különben valami nagy biztosíték abban a fényképben nincsen, mert azok a kivándorló ... hazánkfiai lefotografáltatják magukat ott a falun, hogy azok valami különös, ki nem cserélhető fotográfiák volnának, azt nem tudom belátni és így gyakorlatilag nem is lenne valami nagy haszna ennek.” Ezek alapján a miniszterelnök gróf WiLCZEK Frigyes módosítási javaslatát nem támogatta és erre kérte a képviselőket is; az Országgyülés többsége a fényképek útlevélbe történő elhelyezését elutasította.

Képviselőházi Napló 1901-1906. 271-273. p.

${ }^{7}$ 285/1915. (I. 16.) ME.r.

${ }^{8}$ BACSA

${ }^{9}$ Loc.cit. ; Megállapodás útlevelek és vízumok ügyében.

${ }^{10}$ Illustrated Album Of The League Of Nations. 63. p.

11198 172/1922. (X. 24.) BM.r. ; 128 794/1922. (IX. 30.) PM.r.

12 A kitöltendő rovatok a személyleírásnál (2. oldal) kiegészültek a családi állapottal, vallással és a termettel, illetve az érvényesség oldalán (4. oldal) az utazás céljával. A magyar útlevelek borítójának alapanyaga 1929-től lett kartonpapír, amelyet a külső felületén már vászonnal vontak be.

${ }^{13} \mathrm{Az}$ első füzet alakú francia útlevél 2. oldalán a meghosszabbítások, a 3.-on, azaz második címoldalon került feltüntetésre a tulajdonos neve, 4.-en a foglalkozás és lakcím; a személyleírás a 6., a fénykép a 7. oldalon került elhelyezésre.

1450 000/1934. (III. 26.) PM.r. II. rész 1. pont (1) bekezdés illetve 1 sz. melléklet.

${ }^{15}$ Már a 2646/1927. nyomdai jelzettel ellátott útlevelek esetében alkalmazták.

16 A „,szokásos napszám”-ért férfiaknak fizetett összeg a baranya vármegyei Siklóson 1937-1938-ban napi 2 pengő (havi 48-52 pengő) volt átlagosan.

NAGY

17219 945/1934. (VI. 15.) BM.r.

18 - Az egy évig érvényes (magán)útlevél kiváltásának díja 1934-től 20 pengő volt (ebből 5 pengő bélyegilleték, a fennmaradó rész a kiállítási díj), ha a kedvezményre jogosult volt a kérelmező akkor 4 pengőt (ebből 50 fillér bélyegilleték) kellett fizetnie.

Loc.cit.

- Az egy évig érvényes útlevél kiváltásának díja 1937. március 1-jétől a díj 15 pengőre csökkent, a „szokásos napszámot meg nem haladó keresetből élö személyek” illetve a „közszolgálatban álló alkalmazottak”, a nyugdíjasok és az ő ellátásukat élvező családtagjaik 3,50 pengőt fizettek.

111 111/1937. (II. 11.) BM.kr.

${ }^{19}$ A diplomata útlevelek - és ezen úti okmánnyal nem rendelkező, de államügyben utazók részére kiállított ajánlólevelek kiállítása a m. kir. Külügyminisztérium Elnöki osztályának feladata volt 1933-ig, ekkortól a Protokoll osztálynak ügykörébe helyezték, majd 1938-tól e feladatokat ismét az Elnöki osztály hatáskörébe vonták.

${ }^{20}$ SIMON

${ }^{21}$ Az Országgyülés Alsó és Felső Házának tagjai (azaz az országgyülési képviselők) csak dijköteles (magán)útlevélre voltak jogosultak, amelynek teljes díjtételét voltak kötelesek megfizetni, mivel a m. kir. belügyminiszter állásfoglalása értelmében ,az országgyülés tagjai a köz érdekében müködnek, de nincsenek szolgálatban és így közalkalmazottaknak sem tekinthetők”, ez alól kivételt élveztek ,azok a felsőházi tagok, akik a közszolgálatban lévő tényleges vagy nyugdíjas alkalmazottak, azok a saját maguk és ellátást élvező hozzátartozóik után" a korábbi rendeletekben meghatározott csökkentett díjtételt fizették.

147.273/1930. BM. r.

22241 352/1925. (I. 28.) BM.kr. ; 174 900/1936. (VI. 26.) BM.kr.

23 146 795/1930. (XII. 2) BM.r.

24 138 214/1932. (IV. 15.) BM.kr.

25 1878/V. tc. 391. §.

${ }^{26} 1879 /$ XL. tc. $71 . \S . ; 1903 /$ VI. tc. $15 . \S$.

${ }^{27} 1940$ /XVIII. tc. 10 . §.

2845 216/1912. (IV. 23.) PM.r.

29 Az 1926-ban síknyomtatással készített magyar pengő bankjegyek utánzatai, az 1926 decemberében forgalomba bocsátást követően igen hamar megjelentek, s oly' mennyiségben kerültek forgalomba, hogy 1928-ban új, metszettmélynyomtatással is ellátott pénzjegyeket kezdtek terveztetni, amely gyártása még az év második felében megkezdődött, $\mathrm{s}$ hamarosan kibocsátását kellett megkezdeni; a megelőző sorozat címleteit 1930 és 1935 között kivonták a forgalomból. 
${ }^{30}$ RÉTI

${ }^{31}$ Loc.cit.

32 172 100/1935. (I. 2.) BM.kr.

${ }^{33}$ Az állampolgárság bizonyítása az 1930-as évek közepén 10 évnél nem régebbi állampolgársági bizonyítvánnyal vagy 4 éven belül keltezett illetőségi bizonyítvánnyal történhetett. A kellően ezt igazolni nem tudók esetében a leszármazás alapján is vélelmezhette a hatóság.

34 172 100/1935. (I 2.) BM.kr. op.cit.

${ }^{35} 110$ 000/1937. (I. 30.) BM.kr.

${ }^{36}$ BEDÖ- HODOBAY: 78. p.

37 9564/1936. BM. VII. res. irat hiteles másolata (kelt: 1936.09.08.; másolat kelt: 1936.09.12.) ; DMM.email: marcosgtk@gmail.com

38 141 817/1930. (V. 13.) BM.kr.

39 BUZINKAY

40 A „39039. vitéz Szénásy. Budapest.” nyomdai jelzetű, 81/1721. KÜM iktatószámon, Budapesten, 1941. január 26-án kiállított diplomata útlevél alapján.

SFNM email: simon.f.nandor@freemail.hu

${ }^{41}$ A gyártási folyamat ismertetése a nyomtatás és a könyvkötészet hagyományos szakaszai illetve a nyomdai jelzetek és gyári sorszámok elemzése alapján történik.

${ }^{42} \mathrm{Az}$ összehasonlításhoz a vizsgált korszakban kiállított argentin, ausztrál, bolgár, brit, csehszlovák, dán, dél-afrikai, egyesült államokbeli, francia, görög, holland, iráni, japán, jugoszláv, kanadai, kínai, lengyel, litván, német, olasz, osztrák, perui, román, svájci, svéd és török, valamint Danzig Szabad Város honi hatóságai által, saját állampolgáraik részére kiállított magánútleveleit vettem figyelembe.

43 - BENCSIK: Az útlevélkérdés története Magyarországon a törvényi szabályozástól a második világháborúig. 14-16. sz. ábra.

- 182 155/1936. BM. V. a. irat (kelt: 1936.12.11.);DMM email: marcosgtk@gmail.com

44 2181/1937. Ony. eln. sz. irat (kelt: 1937.01.05., PuszTASZERI Ferenc rendőrségi szakértő által ; DMM email: marcosgtk@gmail.com

${ }^{45}$ HETÉNYI. 89-90. p.

${ }^{46}$ A fenti lapról készült szakértői véleményt összefoglaló szakértői jelentés - amely a vegyszerekkel kezelt felületekröl az akkor frissen szerzett tapasztalatokat részletezi - ammóniák $\left(\mathrm{NH}_{3}\right)$ és fehérítő ( $\mathrm{NaClO}$; Eau de Javelle) hatására sárgás, sósav $(\mathrm{HCl})$ és oxálsav $\left(\mathrm{H}_{2} \mathrm{C}_{2} \mathrm{O}_{4} \cdot 2 \mathrm{H}_{2} \mathrm{O}\right)$ esetében halvány kék, salétromsavnál $\left(\mathrm{HNO}_{3}\right)$ lila elszíneződést fogalmazott meg.

2181/1937. Ony. eln. sz. irat (kelt: 1937.01.05., PuszTASZERI Ferenc rendőrségi szakértő által); DöME Márk magángyüjteménye, email: marcosgtk@gmail.com

Hetvenöt évvel később, a fenti vizsgálatok alapjául szolgáló lapon az ammóniával kezelt felület már látható elváltozást nem hagyott, a higított sósav enyhén marta csak meg a felületet. Többek között a salétromsav, az oxálsav barna árnyalatban színezte meg a papírt, míg a fehérítő kifehérítette a kezelt felületet, amely kék színnel határolódott.

Budapest, 1937. január 4-ére keltezett alnyomatos, felezett ív vegyi próbája; SFNM email: simon.f.nandor@freemail.hu

47 - BORBÉLY - KAPY. 163. p.

- 2181/1937. Ony. eln. sz. irat (kelt: 1937.01.05., PUSZTASZERI Ferenc rendőrségi szakértő által); DMM email: marcosgtk@gmail.com

${ }^{48}$ Budapest, 1937. január 4-ére keltezett alnyomatos, felezett ív vegyi próbája; SFNM email: simon.f.nandor@freemail.hu

${ }^{49}$ A minden második sorban ismétlődő minták az előzőtől az alábbiakban térnek el. A függőleges középtengelyen felül és alul elhelyezett csúcsmintázat kövérebb vagy vékonyabb, előbbi esetében szélesebb, utóbbinál keskenyebb nyílású lándzsalevél-párban nyugszik, alsó csúcsuk, amely a rajta nyugvó törtvonal minta élével - felső csúcsa szabály szerint feljebb vagy lejjebb nyúlik a csúcsmintába - rombuszt alkot, nagyobb vagy kisebb méretüt. Szintén hasonló összefüggés van a mintázatok találkozásánál az ovális által létrehozott két-két háromszög alakú zárvány méretében.

${ }^{50}$ A hasonlóság igen szembetűnő a lándzsalevél-mintázat esetében. LÉGRÁDY Sándor 1939-es 1 pengős postabélyeg-terve. BUZINKAY: op.cit. 59. p.

51 2181/1937. Ony. eln. sz. irat (kelt: 1937.01.05., PuSZTASZERI Ferenc rendőrségi szakértő által); DMM email: marcosgtk@gmail.com

52 A 2. oldal esetében ismert változat, hogy 3., 4., 5. kapcsos zárójele (összefoglaló jele) nem egyenes vonalvezetésü, ellenben a többivel (eltérő évszámú nyomdai jelzetü okmányok esetében is előforduló eltérés); az 5., 6. és 7 . oldalon kialakított meghosszabbítás rovatoknál nyomtatott jelek közötti eltérések nem összefüggőek, vegyesen voltak egyenes és ívelt vonalvezetésüek alkalmazva.

${ }^{53}$ Az 50 filléres címleten függőleges vonalak ívelt szélü hátteret alkotnak az állami címert angyalokkal, az értékjelzést és rozettán a bevezetés évszáma látható; az 5 pengősön a díszített háttér előtt ülő, kardot és címerpajzsot tartó koronás női alak alatt díszítmény közepére helyezett értékjelölő számot a „pengő” szó határolja.

BÖLCSKEI 381. p.

543 450/1943. (VI. 26.) ME.r. 8. §.

${ }^{55}$ Az alnyomat végtelenített halványbarna apró betűs, szöveges szalagmintázata felett a lapoldalnál kisebb felületen zöld vonalkázott mintázat növényeket és az állami címert ábrázolta, amelyre a fekete elöre nyomtatott szöveg került felvitelre.

56 A vizsgált időszakban a szabvány ürlaptól eltérő magánútleveleket állított ki, többek között: Bulgária (a tárgyalt időszakban a Népszövetség tagja), Hollandia (a Népszövetség alapító tagja), Irán (a Népszövetség alapító tagja), Japán, Kína (a Népszövetség alapító tagja), Németország, Románia (a Népszövetség alapító tagja), Svédország (a Népszövetség alapító tagja), Törökország (a Népszövetség tagja) és az Amerikai Egyesült Államok, illetve Danzig Szabad Város (a Népszövetség közvetlen igazgatása alatt álló terület) is. (Németország hontalan úti okmányainak tartalmi elrendezése - a magánútlevelekkel ellentétben - megfelelt a nemzetközi szabványnak.) 
57 Egynyelvủ magánútlevél-ürlapokat alkalmazott, többek között: Franciaország (a Népszövetség alapító tagja), Németország, Olaszország (a Népszövetség alapító tagja, majd 1937-ben megszüntette tagságát), illetve Danzig Szabad Város (a Népszövetség közvetlen igazgatása alatt álló terület) is. Dánia útlevélhatóságai ellenben négynyelvü útlevélürlapokat alkalmaztak, amelyek így dán, francia, angol és német nyelven hordozták az elöre nyomatott szövegeket és a kitöltött adatokat.

${ }^{58}$ Ismert már a 338.326 gyári számú esetében is.

59 Darabanth Bélyegkereskedelmi és Numizmatikai Kft. 179. gyorsárverésének (2012.06.01., 18:00) 11603. katalógusszámú árverési tétele alapján.

60 A tollal az első oldalra átlósan írt engedély szövege hat sorban: „Javítás után — kigyártható Bp 1939 ápr 21 [azonosíthatatlan aláírás] mi. tan."

Darabanth Bélyegkereskedelmi és Numizmatikai Kft. 179. gyorsárverésének (2012.06.01., 18:00) 11603. katalógusszámú árverési tétele alapján.

61 Darabanth Bélyegkereskedelmi és Numizmatikai Kft. 179. gyorsárverésének (2012.06.01., 18:00) 11603. katalógusszámú árverési tétele alapján. op.cit.

${ }^{62}$ A 302.121 és 304.317 gyári számú, 4792/1938. nyomdai jelzetủ útlevél alapján, a 44. oldal fekete előrenyomtatott szövege mindkettő esetében jól kiolvasható.

${ }^{63}$ A 121.325 illetve 121.446 gyári számú 965/1937. nyomdai jelzetű, a 434.941 számú 1683/1939. jelzetủ útlevelekre mindkettő I. díjkategóriás ürlap - nem nyomtatták a bélyegilleték képét; a 040.997 gyári számú 4039/1936. nyomdai jelzetü űrlapon sem bélyegkép, sem illetékkategória nem került nyomtatásra.

DMM email: marcosgtk@gmail.com ; HAM email: arveres@hodo bay.hu

64 Német okmányok esetében 1942-ben került bevezetésre a perforált gyári szám, ez az 1939-ben bevezetett sorszámbélyegzéssel elhelyezett okmányszámot váltotta fel.

${ }_{65}^{6}$ Eddig ismerten az 480.000, 525.000 illetve 535.000 felettiek esetében, feltehetően néhány ezres csoportok.

${ }^{66}$ A 528.873 gyári számú, 1683/1939. nyomdai jelzetű (1944 decemberében kiállított) útlevél borítója alapján. SFNM email: simon.f.nandor@freemail.hu

${ }^{67}$ A könyv(ecske) gyártás hagyományos szakaszai, illetve az ismert gyári sorszámok, borítóváltozatok és kiállítási idejük elemzése alapján.

${ }_{68} 85$ 055/1940. (XI. 14.) BM.r.

69 Így, többek között eltérő sortörések, szavakat és esetenként mondatokat záró pontok hiánya, gondolatjelek hossza és azok hiánya vagy többlete. Az első oldal okmány- és állammegnevezéseit nem zárja pont, eltérő gondolatjelek, nagyobb betűtávok és eltérő ékezetek; az állampolgárság rovat magyar nyelvű szövege első ékezet nélküli: „Allampolgársága:”, előre nyomtatott kitöltése az alaptípustól eltérő betűkkel került feltüntetésre; második oldal gyermekbejegyzés életkor rovatának francia szövege ékezet nélküli: „Age:”. A meghosszabbítás rovatok bélyegzölenyomatainak helyét jelölő körei jelentősen kisebbek, a bennük lévő betük típusa eltérő. A 44. oldal figyelmeztető szövege eltérő betütípussal készült, 9 bekezdésben csak 29 sor terjedelemmel, a második bekezdés első sora ékezet nélkül készült: „Uj”, a „minö” szavakat ékezet nélkül, illetve rövid ékezettel alakították ki.

${ }^{70}$ A 000079 gyári számú M. kir. Követség Bern 563/1945 nyomdai jelzetű útlevél alapján.

DMM email: marcosgtk@gmail.com

${ }^{71} 110$ 000/1937. (I. 30.) BM.kr. op.cit.

72 „Magyar állami nyomda 15.076/1947.” nyomdai jelzetü okmány.

${ }^{73} \mathrm{Az}$ 1930-as évek második felében a magyar útlevél-kiállító hatóságok a fővárosban M. Kir. Rendőrség Budapesti Főkapitánysága, a vármegyékben az alispán, a törvényhatósági jogú városokban a M. Kir. Rendőrség kapitányságai, külföldön a m. kir. követségek illetve konzulátusok voltak.

Az új közigazgatás 1945 júliusától a Magyar Államrendörség területi és törvényhatósági jogú városokban helyi szerveit jelölte ki az útlevelek kizárólagos kiállító hatóságaként.

Külföldön a magyar külképviseletek (követségek, konzulátusok) voltak útlevelek kiállítására és meghosszabbítására feljogosítva.

$74141817 / 1930$. (V. 13.) BM.kr. op.cit.

75 182 155/1936. BM. V. a. irat (kelt: 1936.12.11.); DMM email: marcosgtk@gmail.com

76 198 172/1922. (X. 24.) BM.r. op.cit. ; 110 000/1937. (I. 30.) BM.kr. op.cit.

${ }^{77}$ GÁSPÁR

78 - BORBÉLY - KAPY: op.cit. 163. p.

- 2181/1937. Ony. eln. sz. irat (kelt: 1937.01.05., PuszTASZERI Ferenc rendőrségi szakértő által); DMM email: marcosgtk@gmail.com

${ }^{79}$ Az 1930-as években 72 oldal terjedelmü összeállítás részletesen ismerteti az utónevek francia fordításait, köztük számos rendkívül egyedi névváltozatot, ezen túl a foglalkozásokat igen széles körüen (pl.: bányászati területen érdekelteket és abban dolgozókat 11 meghatározás ismerteti, de található a felsorolásban karnagy, kártyafestő, kötélverő, lóápoló, pénzverő, piaci árus, stb.). A személyleírásnál alkalmazandó kifejezéseket számos megfogalmazás segítette (pl.: termetnél 15, az arc leírásánál 27 kifejezés található). Az országok és világrészek fejezete 39 államot (közte Bajor-, Szászország és „Ukránia”) ismertet, valamint a földrészeket. Ezen felül még további rovatok kitöltésénél alkalmazható szavak, kifejezések és mondatok is megtalálhatóak, valamint egy kimutatás is a magyar külképviseletek jegyzékéről (a cím és a levelezési nyelv ismertetésével is)

Magyar-francia szótár az útlevelet kiállitó hatóságok részére.

80 600/1920 (XII. 14.) BM.r. ; 140 631/1930. (I. 21.) BM.kr.

${ }^{81}$ BERÁNNÉ - Hollós (szerk.). 170-172. p.

82 Általánosnak mondható a fénykép hitelesítésénél a száraz és nedves bélyegzőlenyomat alkalmazása - többek között - a M. Kir. Rendőrség Budapesti Főkapitánysága és a Pest-Pilis-Solt-Kiskun vármegye alispáni hivatala által kiállított útlevelek esetében.

${ }^{83} 110$ 000/1973. (I. 30.) BM.kr. op.cit. 
${ }^{84}$ A leggyakoribb a zöld színủ alkalmazása volt, a színtelen már ritkábban fordult elő és elsősorban az 1940-es években kiállított okmányokban, a többi alkalmazására csak elvétve találni példát.

${ }^{85}$ Azaz a hármashalom-kettőskereszt került a bal oldalra és a jobb oldali lett hétszer vágott mezö.

${ }^{86} 110$ 000/1937. (I. 30.) BM.kr. op.cit.

${ }^{87} 118$ 733/1937. (X. 29.) BM.kr.

${ }^{88}$ A magyar állami Rendőrség 1905-től kezdődően lett útlevélhatóság, majd maradt az - 1914-1920 közötti megszakítással - egészen 1948-ig.

${ }^{89}$ BORBÉLY - KAPY: op.cit. 162-163.p.

90 144/1937. Ony. eln. Sz. irat hivatalos másolata (kelt: 1937.06.28., PuSZTASZERI Ferenc rendőrségi szakértő által; másolat kelte: 1937.10.21., BAKOS rendőrségi kezelő által); DMM email: marcosgtk@gmail.com

${ }^{91}$ 113.238/1937. V. a. sz. irat (kelt: 1937.06.12.); DMM email: marcosgtk@gmail. com

$92 \mathrm{Az}$ ellenőrző lapok a terv szerint a 43. és a 45. oldalon előre (fekete illetve piros színnel) nyomtatott, vonal nélküli táblázatok lettek volna: az okmány vizsgálati nézetéhez képest 90 fokkal elforgatott tíz sorban az ABC 26 betüje lenne olvasható, amelyet jobbra két oszlopban számjegyek „1” és „,0” között zárnának. A jogosult családnevét és születésének évszámát a 43. oldalon lyukasztással alakították volna ki (nevének első betủjével azonosat az első sorban kilyukasztanák, a név második betüjét a második sorban, stb.; a születés évszámának utolsó két számjegyét a számokkal teli oszlopban jelölnék), amely lapját a 45. oldalra (hátsó belső előzék) hajtva, a lyukakon át láthatóvá válna a piros színủ adat.

144/1937. Ony. eln. sz. irat hivatalos másolata (kelt: 1937.06.28., PuszTASZERI Ferenc rendőrségi szakértő által; másolat kelte: 1937.10.21., BAKOS rendőrségi kezelő által); DMM email: marcosgtk@gmail.com

${ }_{93}$ 113.238/1937. V. a. sz. irat (kelt: 1937.06.12.); DMM email: marcosgtk@gmail.com

94 144/1937. Ony. eln. sz. irat hivatalos másolata (kelt: 1937.06.28., PUSZTASZERI Ferenc rendőrségi szakértő által; másolat kelte: 1937.10.21., BAKOs rendőrségi kezelő által); DMM email: marcosgtk@gmail.com

${ }^{95}$ Budapesten, a Magyar Királyi Rendőr-főkapitányság illetékes osztályán még 1944. december 12-én is történt útlevélmeghosszabbítás és vele együtt a kiutazás engedélyezése, holott a szovjet csapatok ekkorra már megszállták Tökölt, Érdet és Vác városát, s azon a napon vonultak be Gödöllöre és Isaszegre is.

${ }^{96}$ BEDÖ- HODOBAY. op.cit. 78. p.

${ }^{97} 152$ 289/1945. (VIII. 21.) BM.r.

98190 057/1947. (I. 3.) BM.r.

${ }^{99}$ Erre jogalapot a magyar Ideiglenes Nemzeti Kormány 1945. március 8-án kelt rendelete adta, amely előírta, hogy az állami hivatalok / hatóságok megnevezésében a „királyi” jelzőt vagy annak rövidítését mellőzni kell.

539/1945. (III. 8.) ME.r.

${ }^{100}$ A belügyminiszter 1945 nyarának legelején javaslattételre a Rendőrség Budapesti Főkapitányságának Útlevél Osztályát utasította, amely szervezeti elem a magyar Állami Nyomdától különböző színü két külalakban tervezett mintaútlevél legyártását rendelte meg bemutatás céljára. Az Útlevél Osztály javaslata kiállt a korábban alkalmazott okmánypapír és vegyi anyagokra érzékeny festékanyaga mellett és előterjesztésében szerepelt a perforált gyári szám alkalmazása is. A tervezett új útlevél méretét tekintve a korábbinál magasságában kisebb, de szélesebb lett volna - zsebben könnyebben hordhatósága okán -, s a borítón ún. ablakot alakítottak volna ki, amelyen át olvasható az okmány gyári és iktatószáma; a javaslat szerint a vászonnal fedett borítón nemzeti színű sávot jelenítettek meg. Az illetékbélyeg képét már nem tervezték elöre nyomtatni, a személyleírás rovatainak sorrendjében az ellenőrzést elősegitő változást javasoltak: a születési hely és idő rovatai legelöre, míg a gyakrabban változó foglalkozás a végére került volna. Az érvényesség oldalán a tervek szerint előre került a lejárat dátuma, alá, a területi érvényesség rovata elöre nyomtatva tartalmazta azt a mondatrészt is, hogy Magyarországra való visszatérésre is jogosít. Új útlevél bevezetésére végül csak 1948 elején került sor, s az sem viselte magán az itt említett, 1945-ös javaslatok legtöbbjét sem (azonban alkalmazták a méretre, lapperforálásra és illetékbélyeg-kép hiányára vonatkozó javaslatokat).

40/1945. fk. útl. eln. sz. irat eredeti másolata (kelt: 1945.07.09., az útlevél osztály vezetője által, az aláírása nélkül), hivatkozással a 135.018/1945. BM. ; DMM email: marcosgtk@gmail.com

${ }^{101}$ Elsősorban a borító nyomatának megoldásából arra lehet következtetni, hogy a fedőlapgyártás és kötés még 1945 második felében megtörténhetett, mivel ekkor hivatalosan még „királyság” volt az államforma, azonban a „királyi” jelzőt 1945 március után használni nem lehetett; így dönthettek a címer alatt kialakított, semleges „Magyarország” és „Hongrie” felirat kialakítása mellett. Mivel a köztársaságot 1946. február 1-jén kiáltották ki, ezért az ezt követő gyártásnál eleve a „Magyar Köztársaság” felirat került volna a koszorús címer alá, vagy az „útlevél” szavak fölé és szükségtelen lett volna az okmánymegnevezés feletti címkével történt, utólagos felülragasztás.

${ }^{102}$ Erre az államrendörség hatóságait az 1946. május 10-én keltezett belügyminiszteri rendelet utasította: ,a »királyi«jelző mind a használatba vett nyomtatványokról, mind pedig a bélyegzőkröl haladéktalanul töröltessék". 229 482/1946. (V. 10.) BM.r.

${ }^{103}$ A magyarhoz hasonló megoldásokat alkalmaztak 1946-tól Bulgáriában is. Itt kezdetben kézzel kihúzták, majd kézírással a köztársaság szavakat írták a régi államforma fölé; hamarosan azonban a cárságra és a cárra utaló részeket az új államforma megnevezését tartalmazó lenyomattal bélyegezték felül.

${ }^{104}$ HAM email: arveres@hodobay.hu

1054 340/1945. (VII. 4.) ME.r.

${ }^{106}$ Loc.cit. ; 159 900/1945. (XI. 29.) BM.r.

${ }^{107} 159$ 900/1945. (XI. 29.) BM.r. op.cit.

108 Loc.cit.

${ }^{109}$ Loc.cit.

110274 778/1946. (IX. 27.) BM.r.

111 BENCSIK - NAGY.15. p.

112 SIMON: op.cit.

113 SAÁRY - VADNAY. 103-105. p.

114 SÁRINGER

115 SAÁRY - VADNAY. op.cit.

${ }^{116}$ Loc.cit. 
${ }^{117}$ Az ammónia $\left(\mathrm{NH}_{3}\right)$ elváltozást nem okozott, a higított sósav $(\mathrm{HCl})$ enyhén marta csak meg a felületet. Többek között a salétromsav $\left(\mathrm{HNO}_{3}\right)$, az oxálsav $\left(\mathrm{H}_{2} \mathrm{C}_{2} \mathrm{O}_{4} \cdot 2 \quad \mathrm{H}_{2} \mathrm{O}\right)$ barna árnyalatban színezte meg a papírt, míg a fehérítő $(\mathrm{NaClO})$ kifehérítette a kezelt felületet, amely kék színnel határolódott.

Budapest, 1937. január 4-ére keltezett alnyomatos, felezett ív vegyi próbája; SFNM email: simon.f.nandor@freemail.hu

118 BENCSIK: A magyar úti okmányok története 1867-1945. 116. p.

119 BORBÉLY - KAPY: op.cit. op.cit. 162-163. p.

$1201938 /$ XV. tc. ; 1939/IV. tc.

121 TIHANYI

122 Az 1950 M magyar útlevél első néhány ezer példányainak nyomdai jelzete: „MNB Pénzjegynyomdája. 2149/1949.” volt.

${ }^{123}$ Magyar, Budapesten 1981. április 15-én kiállított MÁV arcképes igazolvány alapján.

124 SIMON: op.cit.

125 BENCSIK: A magyar úti okmányok története 1867-1945. op.cit. 122. p.

126 1989/15. tvr.

127 2002/II. tv.

128 Transport and Communications Bulletin for Asia and the Far East. ; BENCSIK-NAGY: op.cit. 185. p.

129 A Német Szövetségi Köztársaság 1950-es évek közepétől az 1974-ig, Görögország 1969 végéig, Brazília még az 1970es évek közepén is, Izrael 1981-ig (jobbról balra rendezve), India még 1981-ben, Pakisztán még 1968-ban is, Ausztria 1969ig, Spanyolország 1983-ban, Thaiföld az 1970-es évek végéig, Belgium még 1980-ban is, Ciprus 1990-ben, az Egyesült Királyság 1993 végéig is még ezen elrendezés szerinti útleveleket személyesített meg.

${ }^{130}$ Resolution 1981 ; Resolution 1982 ; Resolution 1986 ; Resolution 1995 ; Resolution 2000 ; Állásfoglalás 2004

131 Resolution 1982. op.cit.

${ }^{132}$ Resolution 2000. op.cit

133 2252/2004. (XII.13.) EK.r. ; 444/2009. (V. 28.) EK.r.

134 Így, többek között az Egyesült Királyság, Németország és Spanyolország útlevélhatósága 1988-ban, Portugália 1989ben, Franciaország 1991-ben, Finnország 1997-ben, Svédország 1998-ban kezdte meg a burgundi vörös borítójú egységes útlevelek kiállítását.

\section{Jegyzetekben alkalmazott röviditések:}

\section{MONOGRÁFIÁK KISMONOGRÁFIÁK ÉS HASONLÓ JELLEGÜ KÖTETEK}

BORBÉLY - KAPY

(47.,78.,89., 119)

BENCSIK: A magyar úti okmányok története 1867-1945.

(118., 125.,)

BENCSIK - NAGY

(111.,128.,)

BUZINKAY

$(39 ., 50 .$,

Magyar posta- és illetékbélyeg katalógus

\section{TANULMÁNYOK}

BACSA

$(8 ., 9 .$,

DIENES

(3.,)

RÉTI

(30.,31.,)

SIMON

(20.,112.,124.,)
- BoRBÉLy Zoltán - KAPY Rezső (szerk.): A 60 éves magyar rendőrség 18811941. Budapest, 1941, Halász Irodalmi és Könyvkiadó Vállalat. 594 p.

- BENCSIK Péter: A magyar úti okmányok története 1867-1945. Budapest, 2003, Tipico Design Kft. 179 p. HU-ISB 9637623337.

- BenCsiK Péter - NAGY György: A magyar úti okmányok története 19451989. Budapest, 2005, Tipico Design Kft. 275 p. HU-ISBN 9637623353.

- Buzinkay Géza: 150 éves az Állami Nyomda. Az első magyar bélyegtöl a chipkártyáig. Budapest, 2001, Állami Nyomda Rt. 103 p. HU-ISBN 96385 67414.

- BöLCSKeI Imréné et al.: Magyar posta- és illetékbélyeg katalógus, 2004. S. 1., 2004, Philatelia Hungarica Kft. 381.p.

- BACsA Gábor: A magyar és jugoszláv optánsok határátlépése.Rendvédelemtörténeti Füzetek (Acta Historiae Preasidii Ordinis), X.évf. (2000) 11.sz. 1014.p. HU-ISSN 1216-6774. A tanulmány korábbi változata 1999. április 20.-án Budapesten hangzott el, a Szemere Bertalan Magyar Rendvédelem-történeti Tudományos Társaság által szervezett rendvédelem-történeti tudományos konferenciasorozatnak „Szabad mozgás a Kárpát-medencében” címü XI. konferenciáján. A publikált tanulmány az előadás javított, bővített és átdolgozott változata.

DiENES Istvánné: Az útlevél hazai történetéböl. 177-234.p. .A Közlekedési Múzeum Évkönyve. VIII.sz. (1985-1987) HU-ISSN 0133-4646.

RÉTI György: Olasz diplomáciai dokumentumok Magyarországról. Korunk, XIV.évf. (2004) 2.sz. 85-90.p. HU-ISSN 1222-8338.

Simon F. Nándor: Villantás egy témára. Séta egy útlevél körül. Rendvédelem-történeti Füzetek (Acta Historiae Praesidii Ordinis), XII.évf. (2007) 15.sz. 170-175.p. A tanulmány korábbi változata 2001. november 6-án Budapesten hangzott el a Szemere Bertalan Magyar Rendvédelem-történeti Tudományos Társaság által szervezett rendvédelem-történeti tudományos konferenciasorozatnak „Az európai és a magyar rendvédelem a XIX-XX. században” címü XV. konferenciáján. A publikált tanulmány az előadás javított, bővített és átdolgozott változata. 
TIHANYI

(121.,)

\section{MEMOIROK}

HETÉNYI

(45.)

\section{ÉLETÚT PORTRÉK}

SAÁRY - VADNAY

(113.,)

CIKKEK

NAGY

(16.,)

\section{SÁRINGER}

(114.,115.,116.,)

\section{ALBUMOK}

Illustrated Album Of The League Of Nations. (10.,)

\section{DOKUMENTUMTÁR KIADVÁNYOK}

BERÁNNÉ - HoLlÓs (szerk.)

\section{KATALÓGUS}

BÖLCSKEI

(53.,)

\section{SZABÁLYZATSEGÉDLET}

Magyar-francia szótár az útlevelet kiállitó hatóságok részére.

(79.,)

\section{KÉZIRATOK}

BEDÖ - HODOBAY

(101.,96.,)

BENCSIK: Az útlevélkérdés története Magyarországon a törvényi szabályozástól a második világháborúig. (43.,)

GÁSPÁR

(77.,)

\section{LEVÉL-, IRAT- ÉS DOKUMENTIMTÁRAK}

DMM 90.,9192.,93.,94.,100.,)

\section{HAM}

(104.,)

Képviselőházi Napló 1901-1906.

(6.,)

SFNM

(40.,48.,66.,117.,)

Transport and Communications Bulletin for Asia and the Far East.

(128.,)

\section{JOGSZABÁLYOK}

1723/XII.tc.

(1.,)

$1878 /$ V.tc.

(25.)

1879/XL. tc.

1903/VI.tc. (26.,)
TiHANYI János: Svájc és Németország viszonya a II. világháború idején. Századok, CXXIII.évf. (1989) 1.sz. 76-124.p. HU-ISSN 0039-8098.

— HetÉnYI Imre: Amikor a rend öre voltam. Budapest, 1941, Pantheon. 272 p.

- SAÁRY Éva - VADNAY Zsuzsa: Érdekes Emberek. Nyugati magyar portrék. Zürich, 1981, Svájci Magyar Irodalmi és Képzőmüvészeti Kör. 139 p. CH-ISBN —

- Nagy Imre Gábor: Siklós a két világháború között (1921-1944). 245-314. p. In VonYó József (szerk.): Város a Tenkes alján. Siklós évszázadai. Siklós, 2000, Siklós Város Önkormányzata. 396 p.HU-ISBN 9630034255.

- SÁringer János: Magyarország és Spanyolország a követi jelentésekben. Aetas, XVIII.évf. (2003) 2.sz. HU-ISSN 0237-7934.

Illustrated Album Of The League Of Nations [A Népszövetség Illusztrált Albuma]. Genf, 1926, Népszövetség Titkárságának Tájékoztatási Osztálya. 83 p.

- Beránné Nemes Éva - Hollós Ervin (szerk.): Megfigyelés alatt... Dokumentumok a horthysta titkosrendörség müködéséböl (1920-1944). Budapest, 1977, Akadémiai Kiadó. 787.p. HU-ISBN 9630509040.

- BöLCSKEI Imréné et al.: Magyar posta-és illetékbélyeg katalógus 2004. Budapest, 2004, Philatélia Hungarica Kft. 428 p. HU-ISBN —

- Magyar-francia szótár az útlevelet ki-állitó hatóságok részére. Budapest, 1928, Stádium Sajtóválallat Részvénytársaság.

- Bedő József - Hodobay Andor: Az illetékdíjjegyes ÚTLEVÉL-ürlapok és felhasználásuk 1905-1947 között. Kézirat, Budapest, 1996-2000. 112 p. HoDOBAY Andor magángyüjteményéből.

- BENCSIK Péter: Az útlevélkérdés története Magyarországon a törvényi szabályozástól a második világháborúig. Ph.D. disszertáció (JPTE). Kézirat, Pécs, 1999.

- GÁSPÁR László: A magyar úti okmányok története 1945-töl 1961-ig. Szakdolgozat (ZMNE). Kézirat, Budapest, 2004.
— HodoBAy Andor magángyüjteménye.

— Képviselőházi Napló 1901-1906. X.köt.

— SIMON F Nándor magángyüjteménye.

Transport and Communications Bulletin for Asia and the Far East. [Szállítási és Hírközlési Közlöny Ázsia és a Távolkelet Számára.], I.évf. (1961) 32.sz. 31-32.p. UN-ISSN 0033-3409.

1723/XII.tc. különféle, eddig hütlenségi bünnek tekintett eseteket, a büntettek minőségéhez képest, enyhébb büntetéssel büntetendőknek jelentenek ki.

— 1878/V.tc. a magyar büntetőtörvénykönyv a büntettekröl és vétségekröl.

— 1879/XL. tc. a magyar büntető törvénykönyv a kihágásokról.

— 1903/VI.tc. az utlevélügyröl. 
1938/XV.tc.

(120.,)

1939/IV.tc.

(26.,120.,)

1940/XVIII.tc.

(27.,)

2002/II.tv.

(127.,)

51 883/1877. (XII. 19.) BM.r.

(3.,)

45 216/1912. (IV. 23.) PM.r.

(28.,)

285/1915. (I. 16.) ME.r.

(7.,)

82 600/1920. (XII. 14.) BM.r. (80.,)

128 794/1922. (IX. 30.) PM.r. (11.,)

198 172/1922. (X. 24.) BM.r. (11.,76.,)

241 352/1925. (I. 28.) BM.kr. (22.,)

140 631/1930. (I. 21.) BM.kr. (80.,)

141 817/1930. (V. 13.) BM.kr. (38.,74.,)

146 795/1930. (XII. 2) BM.r. (23.,)

147.273/1930. BM. r. 138 214/1932. (IV. 15.) BM.kr. (24.,)

50 000/1934. (III. 26.) PM.r. (14.,)

219 945/1934. (VI. 15.) BM.r. (17.,)

172 100/1935. (I. 2.) BM.kr.

174 900/1936. (VI. 26.) BM.kr. (22.,)

110 000/1937. (I. 30.) BM.kr. (35.,)
1938/XV.tc. a társadalmi és a gazdasági élet egyensúlyának hatályosabb biztosításáról.

1939/IV.tc. a zsidók közéleti és gazdasági térfoglalásának korlátozásáról.

1940/XVIII.tc. a magyar állam biztonságát és nemzetközi érdekét veszélyeztető egyes cselekmények büntetéséröl.

- 2002/II.tv. az Egyesült Nemzetek Szervezete keretében New Yorkban, 1954. szeptember 28-án létrejött, a Hontalan Személyek Jogállásáról szóló Egyezmény kihirdetéséröl.

- $\quad 51$ 883/1877. (XII. 19.) BM.r. külföldre szóló útlevelek kiadása és kiállítása tárgyában.

Közigazgatási Döntvénytár, I.évf. (1877) 3.sz. 54-55.p.

- 45 216/1912. (IV. 23.) PM.r.az 1907. évi 20 koronás bankjegyhamisítványok ismertetése tárgyában.

Belügyi Közlöny, XVI.évf. (1912) 25.sz. 193-194.p.

285/1915. (I. 16.) ME.r. az útlevélkötelezettség elrendeléséről. Magyarországi Rendeletek Tára, XLVIII.évf. (1915) 1.sz. 38-40.p.

82 600/1920. (XII. 14.) BM.r. az útlevélkiállítás jogának az 1903:VI. t.-c. 6. §-ában megállapított útlevélkiállító hatóságok hatáskörébe való visszautalásáról. Magyarországi Rendeletek Tára, LI.évf. (1920) 1.sz.768-777.p.

- 128 794/1922. (IX. 30.) PM.r. az uj mintájú bélyeges kincstári utlevélürlapok forgalombabocsátása.

Belügyi Közlöny, XXVI.évf. (1922) 46.sz. 2100-2102.p.

- 198 172/1922. (X. 24.) BM.r. uj mintájú bélyeges kincstári utlevélürlapok forgalombahozatala és az ezzel kapcsolatos intézkedések.

Magyarországi Rendeletek Tára, LV.évf. (1922) 1.sz. 263-267.p.

- 241 352/1925. (I. 28.) BM.kr. a Szent Év alkalmából a katholikus hívők által Rómába tervezett zarándoklatokban réssztvevőknek az útlevélkötelezettség alól való felmentése.

Belügyi Közlöny, XXIX.évf. (1925) 5.sz. 103-104.p.

— 140 631/1930. (I. 21.) BM.kr. az útlevelek kiállításához szükséges magyarfrancia szótár kiigazítása.

Belügyi Közlöny, XXXV.évf. (1930) 7.sz. 129.p.

- 141 817/1930. (V. 13.) BM.kr. a bélyeges útlevélürlapok beszerzése, valamint az elrontott ürlapok kicserélésére vonatkozó rendelkezések újabb módosítása.

Belügyi Közlöny, XXXV.évf. (1930) 28.sz. 504-506.p.

- 146 795/1930. (XII. 2) BM.r. Ausztriába és Németországba utazó 15 éven aluli kiskorú gyermekek részére kiállítható útlevelet pótló igazolványról, valamint az Ausztriai viszonylatban engedélyezett, és csoportos utazásoknál használható „,csoportos névjegyzék”-röl.

Magyarországi Rendeletek Tára, LXIII.évf. (1930) 1.sz. 874-875.p.

- 147.273/1930. BM. r.

- $\quad 138$ 214/1932. (IV. 15.) BM.kr. tengerészeti könyveknek a határátlépés alkalmával útlevélpótló okmányként elfogadásáról.

Magyarországi Rendeletek Tára, LXV.évf. (1932) 1.sz. 369-370.p.

- 50 000/1934. (III. 26.) PM.r. a forgalomban lévő kincstári bélyegekről és bélyeges ürlapokról, és azok tekintetében 1934. évi április hó 1-én bekövetkező változásokról.

Magyarországi Rendeletek Tára, LXVII.évf. (1934) 1.sz. 346-367.p.

- 219 945/1934. (VI. 15.) BM.r. a 70.000/1904. B. M. rendelet 29. §-ának újabb módosításáról.

Magyarországi Rendeletek Tára, LXVII.évf. (1934) 1.sz. 498.p.

- 172 100/1935. (I. 2.) BM.kr. az útlevelek kiállítása alkalmával követendő eljárás. Magyarországi Rendeletek Tára, LXVIII.évf. (1935) 1.sz. 50-52.p.

- 174 900/1936. (VI. 26.) BM.kr. külföldre csoportos utazások szabályozásáról. Magyarországi Rendeletek Tára, LXIX.évf. (1936) 1.sz. 661-665.p.

- $\quad 110$ 000/1937. (I. 30.) BM.kr. új mintájú útlevelek forgalombahozatala és az ezzel kapcsolatos intézkedések.

Magyarországi Rendeletek Társa, LXX.évf. (1937) 1.sz. 71-73.p. 
111 111/1937. (II. 11.) BM.kr. (18.,)

118 733/1937. (X. 29.) BM.kr. (87.,)

85 055/1940. (XI. 14.) BM.r. (68.,)

3 450/1943. (VI. 26.) ME.r.

(54.,)

539/1945. (III. 8.) ME.r.

4 340/1945. (VII. 4.) ME.r. (105.)

152 289/1945. (VIII. 21.) BM.r.

(97.,)

159 900/1945. (XI. 29.) BM.r. (106.,)

229 482/1946. (V. 10.) BM.r. (102.,)

274 778/1946. (IX. 27.) BM.r.

(110.,)

190 057/1947. (I. 3.) BM.r. (98.,)

1989/15. tvr.

(126.,)

2252/2004. (XII.13.) EK.r. (133.,)

444/2009. (V. 28.) EK.r. (133.,)

NEMZETKÖZI EGYEZMÉNYEK Megállapodás útlevelek és vízumok ügyében.

(9.,)

NEMZETKÖZI ÁLLÁSFOGLALÁSOK

Állásfoglalás 2004 (130.,)

Resolution 1981

(130.,)
- $\quad 111$ 111/1937. (II. 11.) BM.kr. az útlevélkiállítási díjak újabb megállapítása. Magyarországi Rendeletek Tára, LXX.évf. (1937) 1.sz. 77-79.p.

- $\quad 118$ 733/1937. (X. 29.) BM.kr. az új mintájú útlevelek kiállításánál a fényképek beragasztásának mellőzése. Külügyi Közlöny, XVII.évf. (1937) 11.sz. 88.p.

— $\quad 85$ 055/1940. (XI. 14.) BM.r. szolgálati útlevelek rendszeresítése. Belügyi Közlöny, XLVI.évf. (1940) 52.sz. 1793.p.

— 3 450/1943. (VI. 26.) ME.r. az állandó összegü illetékek újabb megállapításáról. Magyarországi Rendeletek Tára, LXXVI.évf. (1943) 1464-1516.p.

- 539/1945. (III. 8.) ME.r. az államhatalom gyakorlásával kapcsolatos egyes kérdések rendezéséröl.

Magyarországi Rendeletek Tára, LXXVIII.évf. (1945) 1.sz. 53-54.p.

- $\quad 4$ 340/1945. (VII. 4.) ME.r. az útlevélügy újabb szabályozása tárgyában. Rendörségi Közlöny, I.évf. (1945) 6.sz. 87-88.p.

- $\quad 152$ 289/1945. (VIII. 21.) BM.r. a határátlépés szabályozása tárgyában. Rendörségi Közlöny, I.évf. (1945) 6.sz. 88.p.

— $\quad 159$ 900/1945. (XI. 29.) BM.r. az útlevelek kiállítása körüli eljárás szabályozása tárgyában. Rendörségi Közlöny, I.évf. (1945) 12.sz. 275-277.p.

- 229 482/1946. (V. 10.) BM.r. az állami hatóságok és szervek megjelölésénél és címénél a „királyi” jelző használatának mellőzése. Rendörségi Közlöny, II.évf. (1946) 12.sz. 373.p.

— $\quad 274$ 778/1946. (IX. 27.) BM.r. az útlevelek kiállításánál az elöírt szabályok betartása tárgyában.

Rendörségi Közlöny, II.évf. (1946) 22.sz. 601.p.

- 190 057/1947. (I. 3.) BM.r. a határátlépésre vonatkozó rendelkezések összefoglalásáról szóló 411.728/1946. IV-12. B. M. rendelet egyes rendelkezéseinek újabb módosítása és kiegészítése.

Rendörségi Közlöny, III.évf. (1947) 2.sz. 41.p.

- 1989/15. tvr. a menekültek helyzetére vonatkozó 1951. évi július hó 28. napján elfogadott egyezmény valamint a menekültek helyzetére vonatkozóan az 1967. évi január hó 31. napján létrejött jegyzőkönyv kihirdetéséről.

Törvények és Rendeletek Hivatalos Gyüjteménye, XXXVII.évf. (1989) $434-$ 453.p.

- 2252/2004. (XII.13.) EK.r. a tagállamok által kiállított útlevelek és úti okmányok biztonsági jellemzőire és biometrikus elemeire vonatkozó elöírásokról.

Az Európai Unió Hivatalos Lapja, XLVII.évf. (2004) L385.sz. 1-6.p.

- 444/2009. (V. 28.) EK.r. a tagállamok által kiállított útlevelek és úti okmányok biztonsági jellemzőire és biometrikus elemeire vonatkozó elöírásokról szóló 2252/ 2004/EK tanácsi rendelet módosításáról. Az Európai Unió Hivatalos Lapja, XLII.évf. (2009) L142.sz. 1-4.p.

A Graz-ban, 1922. január 27-én Ausztria, Csehszlovákia, Magyarország, Olaszország, Lengyelország, Románia és a Szerb-Horvát-Szlovén Királyság által kötött megállapodás útlevelek és vízumok ügyében.

A 2004. június 8-ai Tanács keretében ülésező tagállami kormányképviselőknek az egységes útlevél bevezetéséről szóló 1981. június 23-ai, 1982. június 30-ai, 1986. július 14-ei és 1995. július 10-ei állásfoglalásokat kiegészítő állásfoglalása.

Hivatalos Lap (az Európai Unió hivatalos lapja), 47. évf. (2004) C 245 sz., 1. p.

- Resolution of the Representatives of the Governments of the Member States of the European Communities, meeting within the Council of 23 June 1981. [Az 1981. június 23-ai Tanács keretében ülésező tagállami kormányképviselőknek állásfoglalása.]

Official Journal (az Európai Unió hivatalos lapja), 24. évf. (1981) C 241, 1-7. p. 
Resolution 1982

$(130 ., 131 .$,

Resolution 1986

$(130 .$,

Resolution 1995

(130.,)

Resolution 2000

$(130 ., 132 .$,
Supplementary Resolution to the Resolution adopted on 23 June 1981 concerning the adoption of a passport of uniform pattern, of the Representatives of the Governments of the Member States of the European Communities, meeting within the Council on 30 June 1982. [Az 1982. június 30-ai Tanács keretében ülésező tagállami kormányképviselőknek az egységes útlevél bevezetéséről szóló 1981. június 23-ai állásfoglalást kiegészítő állásfoglalása.]

Official Journal (az Európai Unió hivatalos lapja), 25. évf. (1982) C 179, 1-2. p.

Resolution of the Representatives of the Governments of the Member States, meeting within the Council, of 14 July 1986 supplementary to the resolutions of 23 June 1981 and 30 June 1982 concerning the introduction of a passport of uniform pattern. [Az 1986. július 14-ei Tanács keretében ülésező tagállami kormányképviselőknek az egységes útlevél bevezetéséről szóló 1981. június 23-ai és 1982. június 30-ai állásfoglalásokat kiegészítő állásfoglalása.]

Official Journal (az Európai Unió hivatalos lapja), 29. évf. (1986) C 185, 1. p.

Resolution of the representatives of the Governments of the Member States, meeting within the Council of 10 July 1995 supplementary to the resolutions of 23 June 1981, 30 June 1982 and 14 July 1986 concerning the introduction of a passport of uniform pattern. [Az 1995. július 10-ei Tanács keretében ülésező tagállami kormányképviselőknek az egységes útlevél bevezetéséről szóló 1981. június 23-ai, 1982. június 30-ai és 1986. július 14-ei állásfoglalásokat kiegészítő állásfoglalása.]

Official Journal (az Európai Unió hivatalos lapja), 38. évf. (1995) C 200, 1. p.

Resolution of the representatives of the governments of the Member States, meeting within the Council of 17 October 2000 supplementing the resolutions of 23 June 1981, 30 June 1982, 14 July 1986 and 10 July 1995 as regards the security characteristics of passports and other travel documents. [Az 2000. október 17-ei Tanács keretében ülésező tagállami kormányképviselőknek az egységes útlevél bevezetéséröl szóló 1981. június 23-ai, 1982. június 30-ai, 1986. július 14-ei és 1995. július 10-ei állásfoglalásokat kiegészítő állásfoglalása.]

Official Journal (az Európai Unió hivatalos lapja), 43. évf. (2000) C 310, 1-4. p.

\section{Glosszárium:}

Alnyomat, más néven alapnyomat. Szöveg alatti rétegben nyomtatott, kevésbé erőteljes, de jól kivehető mintázattal kialakított felület, amelyet az okmánygyártás során a meghamisítás felismerésének elősegítésére alkalmaznak.

Előre nyomtatott szöveg. Az alnyomatra nyomtatott felirat vagy ábra, amely azonos csoporton belül minden okmányban állandó; ilyen a tájékoztató / figyelmeztető szöveg, a felhívás a hatóságok részére, a rovatcím, címoldal, stb. is.

Gyürükapocs, korabeli elnevezése lyukszeg volt, német eredetü megnevezése ringli. Elsősorban fénykép rögzítéséhez használt eszköz, amely során fém, peremes henger alakzatot prés segítségével tömörítenek a kívánt alakzatra, így az arcmást csak ezen gyürü eltávolítása után lehet elmozdítani.

Magasnyomtatás. Olyan nyomtatási eljárás, amely során a lenyomat rajzolatának tükörképét alkotó, festéket hordozó felület kiemelkedik a nyomó felület síkjából. Jellegzetessége a nyomás hatására, a kiemelkedő nyomó felület peremén túlra préselődő festék alkotta festékváll. A leggyakoribb általános nyomtatási eljárás a XX. század harmadik harmadáig.

Perforáció. A papír felültének folytonosságának lyukasztással történő megszakítása. Történhet átszúrással / bemetszéssel vagy lyukak létrehozásával. Az okmánygyártás során elsősorban utóbbit alkalmazzák betűk, számok létrehozása céljából.

Szárazbélyegző lenyomat. Kézi vagy asztali prés segítségével, homorú és az azzal megegyező domború lemezpár (klisé) által készített dombornyomtatott kép; általában - fénykép vagy bejegyzés - hitelesítéséhez alkalmazzák.

Útlevélürlap vagy útlevélnyomtatvány. A készre gyártott, megszemélyesítésre szánt kitöltetlen útlevelek elnevezése; amennyiben azok elöre nyomtatva a bélyegilleték képét is tartalmazták (1905 és 1948 között), úgy gyakorta bélyeges útlevélürlap vagy bélyeges útlevélnyomtatvány módon nevezték meg; sokszor alkalmazott, közkeletủ megnevezése „,biankó útlevél”. Az útlevelet kérelmező formanyomtatvány neve „útlevél-lap” volt, amely 1927-től 44 kitöltendő rovaton / kérdésen keresztül volt hivatott adatot szolgáltatni a kiállító hatóság részére.

Vasgallusz, más néven: vastinta, vagy ritkábban gubacstinta. Ezen, íráshoz használt festékoldat - néhány további adalékanyag mellett - elsősorban vas(III)-szulfát $\left(\mathrm{Fe}_{2}\left(\mathrm{SO}_{4}\right)_{3}\right)$ és galluszsav $\left(\mathrm{C}_{7} \mathrm{H}_{6} \mathrm{O}_{5}\right)$ elegye. Víz nem oldja, és a savak is általában csak elhalványítják. E tinta alap-összetétele már több évszázada ismert volt.

Web: Egy 17. századi könyv restaurálása. Web: http://www.szekelyfoldert.info/ 2012.04.19-e 18:20-i állapot szerint.

Vízjel. A papír gyártása során a papírrostok vastagságának eltérésével létrehozott felület, amely átmenő fény segítségével látható ábrát vagy szöveget jelenít meg, ez által beazonosítható a hordozóanyag eredete / eredetisége. A negatív vízjel a fényt jobban áteresztő, vékonyabb felület, míg a pozitív vízjel a vastagabbat, fényt kevésbé áteresztőt jelenti. Okmánygyártás során fontos védelmi elem, mivel utólagosan csak merőben eltérő eljárással és a XX. század végén is csak gyengébb minőséggel volt utánozható. A vízjel alkalmazásának kezdeti évszázadaiban szinte kizárólag vonalas rajzolatú negatív (a papír vékony felületének jobb fényáteresztő-képessége miatt láthatóvá váló) vízjelet alkalmaztak, azonban a XIX. század második felében az Amerikai Egyesült Államok útlevélhatósága már rendkívül jól kidolgozott, szép árnyalatos vízjelet (azaz negatív és pozitív felületek éles határvonal nélkül, fokozatosan térnek át a másik felületbe) tartalmazó útleveleket állított ki (később ettől egyszerübb kivitelt vezettek be). 